\title{
Hesperiidae of Rondônia, Brazil: Cephise Evans (Pyrginae), with descriptions of new species from Mexico and Brazil
}

\author{
George T. Austin ${ }^{2}$ \\ Olaf H.H. Mielke ${ }^{3}$
}

\begin{abstract}
The species of Cephise Evans, 1953 are divided in two groups: "cephise" group (hind wing without long tails) and "procerus" group (hind wing with long tails). In the "cephise" group the following species are included: Cephise cephise (HerrichSchäffer, 1869) with his synonyms Thymele hydarnes Mabille, syn.n., Eudamus zopyrus Plötz, 1881, Telemiades injuncta Plötz, 1882, nom. nud., Eudamus maneros Mabille, 1883, syn.n., Nascus orima Schaus, 1902, syn.n., Nascus orita Schaus, 1902; Cephise impunctus sp.n. from Rondônia, Brazil; Cephise glarus (Mabille, 1888), sp. reval.; Cephise nuspesez Burns, 1996; Cephise malesedis sp.n. from Rondônia, Brazil; Cephise maculatus sp.n. from Rondônia, Brazil; Cephise burnsi sp.n. from Espírito Santo, Brazil; Cephise mexicanus sp.n. from Oaxaca and San Luis Potosi, Mexico. In the "procerus" group are included: Cephise procerus (Plötz, 1880); Cephise aelius (Plötz, 1880) sp. reval., comb.n., with its synonyms Eudamus auginulus Godman \& Salvin, 1893, syn.n. and Eudamus callicina Schaus, 1902, syn.n.; Cephise callias (Mabille, 1888); and Cephise guatemalaensis (Freeman, 1977). Lectotypes are designated for Eudamus cephise Herrich-Schäffer, 1869, Thymele hydarnes Mabille, 1877, Telegonus glarus Mabille, 1988, Eudamus callias Mabille, 1888, Goniurus procerus Plötz, 1888, and Goniurus aelius Plötz, 1880. Neotypes are designated for Eudamus zopyrus Plötz, 1881, and Thymele maneros Mabille, 1883. A pseudotype of Thymele hydarnes is identified, this is actually a female of Cephise impunctus sp.n. Six species of Cephise occur sympatrically in Rondônia, Brazil.

KEY WORDS. Hesperiidae, Cephise, systematics, neotropical
\end{abstract}

This paper continues the studies of the hesperiid (Lepidoptera: Hesperiidae) fauna from the vicinity of Cacaulândia, in central Rondônia, Brazil. The genus Cephise Evans, 1952 (Pyrginae) is treated herein. Methodology is as in a previous paper (AUSTIN \& MIELKE 1997). Times of collection (when known) and dissection numbers ("GTA \#", "OM \#", "DZ \#” [UFPC], "SRS \#”) are given.

Specimens examined are deposited at the following museums: Allyn Museum of Entomology, Sarasota, Florida(AME); American Museum of Natural History, New York (AMNH); Carnegie Museum, Pittsburgh (CM); Museum für Naturkunde, Berlin, Germany (ZMHB); The Natural History Museum, London (BMNH); Nevada State Museum, Las Vegas (NSM); collection of O.H.H. Mielke, Departamento de Zoologia, Universidade Fedeal do Paraná (OM); Universidade Federal do Paraná, Curitiba (UFPC); and National Museum of Natural History, Washington, D.C. (USNM).

1) Contribuição número 1057 do Departamento de Zoologia, Universidade Federal do Paraná

2) Nevada State Museum and Historical Society. 700 Twin Lakes Drive, Las Vegas, Nevada 89107

3) Departamento de Zoologia, Universidade Federal do Paraná. Caixa Postal 19020 , 81531-990 Curitiba, Paraná, Brasil. Fellow CNPq. 


\section{Cephise Evans, 1952}

Evans (1952) erected Cephise to include two taxa (plus six synonyms) of uncertain affinities with an elongate forewing, a produced tornus on the hindwing, and a long costal fold. The male genitalia were characterized as having a conspicuous tuft of hair on the tegumen, an uncus with a broad caudal end, and a thin caudal process ("style") on the ampulla. Evans (1952) placed the genus in his "D" group based on venation and sexual dimorphism in color of macules. FrEEMAN (1970) suggested affinity of Cephise with Urbanus and Astraptes in Evans' (1952) "C" group because of their pattern of flight and their perching behavior including resting with the wings erect beneath leaves. In addition, FrEEMAN (1970) correctly pointed out that Evans' (1952) two subspecies represented different species, Cephise cephise (Herrich-Schäffer, 1869) and Cephise hydarnes (Mabille, 1877). These have different arrangements of macules on both males and females and the male genitalia are very different. BURNS (1996) further diagnosed the genus, recognized that it included several (including tailed) species, added three taxa previously included in Polythrix Watson, 1893, illustrated the types of three names, discussed synonymies, and described and illustrated a new species from Costa Rica. A brief recharacterization of the genus (after BURNS 1996) includes species with or without tails and having palpi with outwardly turned scales forming a triangular shelf beneath the eyes. Males have a broad, truncated, and undivided uncus; an undivided gnathos; a valva with or without a style from the ampulla; an aedeagus with a short and bluntly sloping cephalad end; and numerous, spike-like cornuti. Female genitalia usually have a broad lamella postvaginalis with a broadly U- or V-shaped caudal margin, a generally Y-shaped sclerotization from the ductus bursae to and around the ostium bursae, a pair of heavily sclerotized and often strongly serrated sterigmal plates laterad, and usually a strongly sclerotized area on the side of the ductus bursae. The ventral side of the sterigma cephalad has a more or less funnel-shape and the lamella antevaginalis extends variably caudad and has an often notched caudal edge. The distribution of the genus extends from Mexico to Argentina. Known larval hostplants are in the Combretaceae, Eyrthroxylaceae, Malpighiaceae, and Rubiaceae (BuRNs 1996). Cephise are very rare in collections as noted by BURNS (1996) and, in Rondônia, males fly for but a short period after mid-afternoon, are often in association with army ant swarms (especially Eciton Latreille, 1804, Hymenoptera: Formicidae; see AUSTIN et al. 1993), may be attracted with paper lures, and are occasionally found at lights at night. During the heat of midday, they rest beneath leaves (FREEMAN 1970). MiELKE has found females only on flowers. This general rarity, sexual dimorphism in wing shape and color (in the "cephise" group), superficial similarity among many of the species, the absence of types for two names, and failure to examine extant types has led to a widespread misapplication of names and incorrect synonymies. Indeed, BURNS (1996) admitted that certain names, including some that he used, might not be applied correctly and observed that EvANS' (1952) synonymy might not reflect reality. 
During studies in Rondônia, six sympatric species of Cephise were identified of which three are undescribed. Mielke examined types of most of the taxa associated with Cephise and individuals from other areas were examined during this study including additional new species from eastern Brazil and Mexico. This study has resulted in a synonymy different from common usage.

\section{Key to the species of Cephise}

1. Hindwing with long tail - "procerus" group $\ldots \ldots \ldots \ldots \ldots \ldots \ldots \ldots \ldots$

- Hindwing without long tail - "cephise" group ................. 5

2. Ventral hindwing dark markings poorly developed; valva of male genitalia relatively straight, short, and tapered; female genitalia with caudal edge of lamella postvaginalis deeply V-shaped, lamella antevaginalis short and broad ................................... aelius

- Ventral hindwing dark markings bold and prominent, male and female genitalia shaped otherwise . . . . . . . . . . . . . . . . . . . . 3

3. Male genitalia with valva very long and tapered, female genitalia with lateral plates of sterigma strongly serrate .............. guatemalaensis

- Male genitalia with valva shorter and recurved, female genitalia with lateral plates smooth ...................................4

4. Forewing macule in $\mathrm{M}_{3}-\mathrm{Cu} \mathrm{A}_{1}$ barely overlapping that in $\mathrm{CuA}_{1}-\mathrm{CuA}_{2}$ and not overlapping discal cell macule ..................... procerus

- Forewing macule in $\mathrm{M}_{3}-\mathrm{CuA} \mathrm{A}_{1}$ broadly overlapping that in $\mathrm{CuA}_{1}-\mathrm{CuA}_{2}$ and slightly overlapping discal cell macule $\ldots \ldots \ldots \ldots \ldots \ldots \ldots$ callias

5. Dorsal overscaling red-brown, ampulla of male genitalia with very long style . . glarus

- Dorsal overscaling ochreous or olive, ampulla of male genitalia with shorter or

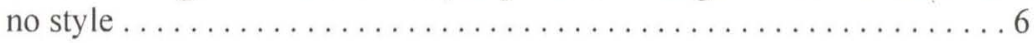

6. Ventral hindwing postmedial band macular; male genitalia without style, valva elongate and tapering gradually to rounded caudal end, slightly upcurved, female unknown ............................ maculatus

- Ventral hindwing postmedial band continuous (often vague), male genitalia without above combination of characters, female genitalia variable . ....7

7. Male dorsal hindwing postmedial band prominent anteriorly, ventral hindwing postmedial band broad, male genitalia with very short style, harpe elongate, upturned to pointed caudal end and with triangular dorsal process, female genitalia with lateral plates of sterigma having elongated caudal teeth ..... burnsi

- Male without above combination of characters, female genitalia with lateral plates of sterigma not having obviously elongated teeth .............. 8

8. Male genitalia with harpe blade-like, not prominently upcurved, not with prominent dorsal process, female genitalia with lateral plates of sterigma always serrate, curved outward caudad . . . . . . . . . . . . . . . . 9 
- Male genitalia with harpe not blade-like, either prominently upcurved or with prominent dorsal process, female genitalia with lateral plates of sterigma not serrate or not curved outward . . . . . . . . . . . . . . . . . 10

9. Forewing macules as compact band, ampulla of male genitalia with long style, female with long lamella antevaginalis ............... impunctus

- Forewing macules less compact with brown patch at base of cell $\mathrm{M}_{3}-\mathrm{CuA}_{1}$, ampulla of male genitalia with no or very short style, female with short

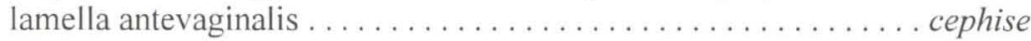

10. Male genitalia with caudal end of harpe prominently upturned, harpe with no dorsal process, female with lateral plates of sterigma not serrate ...mexicanus

- Male genitalia with caudal end of harpe not prominently upturned, harpe with dorsal process, female with lateral plates of sterigma serrate . . . . . . . 11

11. Male genitalia with ampulla having long style, harpe with two dorsal lobes, female with long lamella antevaginalis deeply excavate in center of caudal margin ................................... malesedis

- Male genitalia with ampulla having short style, harpe with no dorsal lobes, female with short lamella antevaginalis not deeply excavate on caudal margin .... nuspesez

\section{"cephise" group}

As noted above, Burns (1996) showed that Cephise included both tailed and untailed species. For convenience, then, the genus is here tentatively separated into two species groups based on this character. The "cephise" group includes the tailless species; these also show marked sexual dimorphism in color and wing shape. Five species of this group occur in central Rondônia.

\section{Cephise cephise (Herrich-Schäffer, 1869)}

Figs 1-4, 9, 20-23

Eudamus cephise Herrich-Schäffer, 1869 (TL: unknown [USA to tropical America], male type at $\mathrm{BMNH}$, herein designated as the lectotype).

Thymele hydarnes Mabille, 1877 (TL: Brazil, female type at BMNH, herein designated as the lectotype); syn.n.

Eudamus zopyrus Plötz, 1881 (TL: Surinam, female type missing, holotype of Nascus orita Schaus, 1902, herein designated as the neotype).

Telemiades cephise; Plötz, 1882.

Telemiades injuncta Plötz, 1882; nomen nudum (ICZN, Art. 11.6.) [= Venada advena (Mabille, 1889)].

Thymele maneros Mabille, 1883 (TL: Brazil, female type missing, holotype of Nascus orita Schaus, 1902, herein designated as the neotype); syn.n.

Nascus orima Schaus, 1902 (TL: Petrópolis, [Estado do Rio de Janeiro, Brazil], male holotype at USNM); syn.n.

Figs 1-8. (1-2) Cephise cephise male, dorsal and ventral, Brazil: Santa Catarina; Joinville, Rio da Prata, 1 May 1980; (3-4) C. cephise female, dorsal and ventral, same data as Figs 1-2; (5-6) C. impunctus male, dorsal and ventral, holotype; (7-8) C. impunctus female, dorsal and ventral, allotype. 

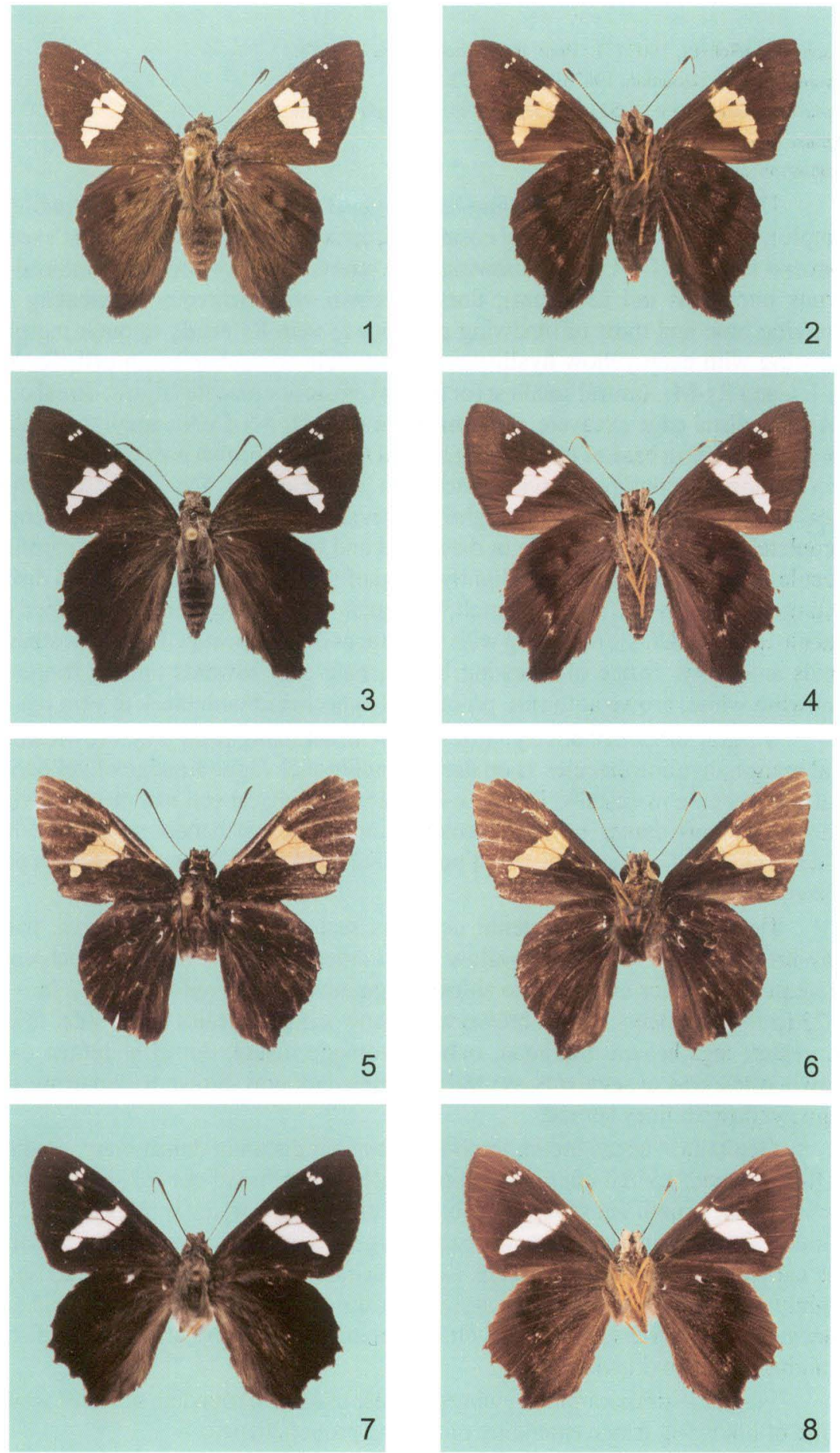

Revta bras. Zool. 17 (3): 757 - 788, 2000 
Nascus orita Schaus, 1902 (TL: Peru, female holotype at USNM).

Thymele zopyrus: Godman, 1907; Draudt, 1922.

Cephise cephise; Evans, 1952; syn.: zopyrus, injuncta, glarus, orita.

Cephise orima; Burns, 1996.

Cephise orita; Burns, 1996.

Description. Male - forewing length $=21.3 \mathrm{~mm}(18.0-22.7, \mathrm{n}=7$; Rondônia sample); forewing with very long costal fold, apex rounded, termen convex except concave between $\mathrm{CuA}_{2}-2 \mathrm{~A}$; hindwing with termen broadly convex, produced at tornus into short tail $(2-3 \mathrm{~mm})$; dorsum brown with ochreous overscaling on forewing base and most of hindwing posterior to vein Rs nearly to outer margin; forewing with deep yellow hyaline macules as follows: subapical in cells $\mathrm{R}_{3}-\mathrm{R}_{4}$, $\mathrm{R}_{4}-\mathrm{R}_{5}$, and $\mathrm{R}_{5}-\mathrm{M}_{1}$, central smallest (or absent), posterior macule largest; discal cell, quadrate, distal edge excavate, proximal edge straight; $\mathrm{M}_{3}-\mathrm{CuA}_{1}$, small triangular, not quite reaching base of cell leaving a small triangular brown area there, partially overlapping or contiguous with macule in discal cell; $\mathrm{CuA}_{1}-\mathrm{CuA}_{2}$, quadrate, excavate on distal edge, very slightly excavate or straight on proximal edge, completely overlapping macule in discal cell and overlapping entirely or partially macule in $\mathrm{M}_{3}-\mathrm{CuA}_{1}$, extending slightly basad of proximal edge of macule in discal cell; upper portion of $\mathrm{CuA}_{2}-2 \mathrm{~A}$, small, triangular, nearly completely overlapped by macule in $\mathrm{CuA}_{1}-\mathrm{CuA}_{2}$; hindwing with faint traces of dark postmedial and postbasal bands anteriorly; fringe of forewing brown, pale gray towards tornus; fringe of hindwing white, brown at tornus, prominently checkered with black at vein tips.

Ventral surface relatively uniform brown; forewing paler gray-brown along anal margin; hyaline macules as on dorsum; additional vague smudge of yellowish scales or macule in costal cell and Sc- $\mathrm{R}_{1}$ anterior to discal cell macule; hindwing with continuous darker brown postmedial and postbasal bands; prominent, but ill-defined, whitish macule distad of postmedial band in cell $\mathrm{CuA}_{2}-2 \mathrm{~A}$, this as pair of conjoined chevrons.

Head brown with scattered ochreous scales, whitish around eyes, palpi gray-brown with scattered pale yellow scales, antennae black on dorsum, ochreous on venter, this color extending to sides at segments, nudum red-brown, $22(\mathrm{n}=2)$ or $23(n=4)$ segments; thorax brown with many ochreous scales on dorsum, fewer on venter, legs brown proximad, ochreous-orange distad; dorsal abdomen dark brown, often gray at segments, ventral abdomen dark gray-brown with narrow and vague yellowish lines laterad.

Genitalia - uncus broad, undivided, pointed distad in dorsal view; gnathos well-developed, caudal ends free, joined cephalad in broad curved shelf; valvae symmetrical, ampulla-costa broad, more or less rectangular, not separable, style on ampulla absent or as very short nub, caudal edge of ampulla concave, harpe variable but narrow, dorsal margin straight except caudal end, this produced into short slightly upturned process; aedeagus slightly shorter than valva, stout, cephalad end truncate in lateral view, caudal end blunt, cornuti of 6-7 robust spikes, those distad straight, those proximad curved.

Female - similar to male; wings broader and more rounded; macules white; white of hindwing fringe extending onto wing proper at apex. 

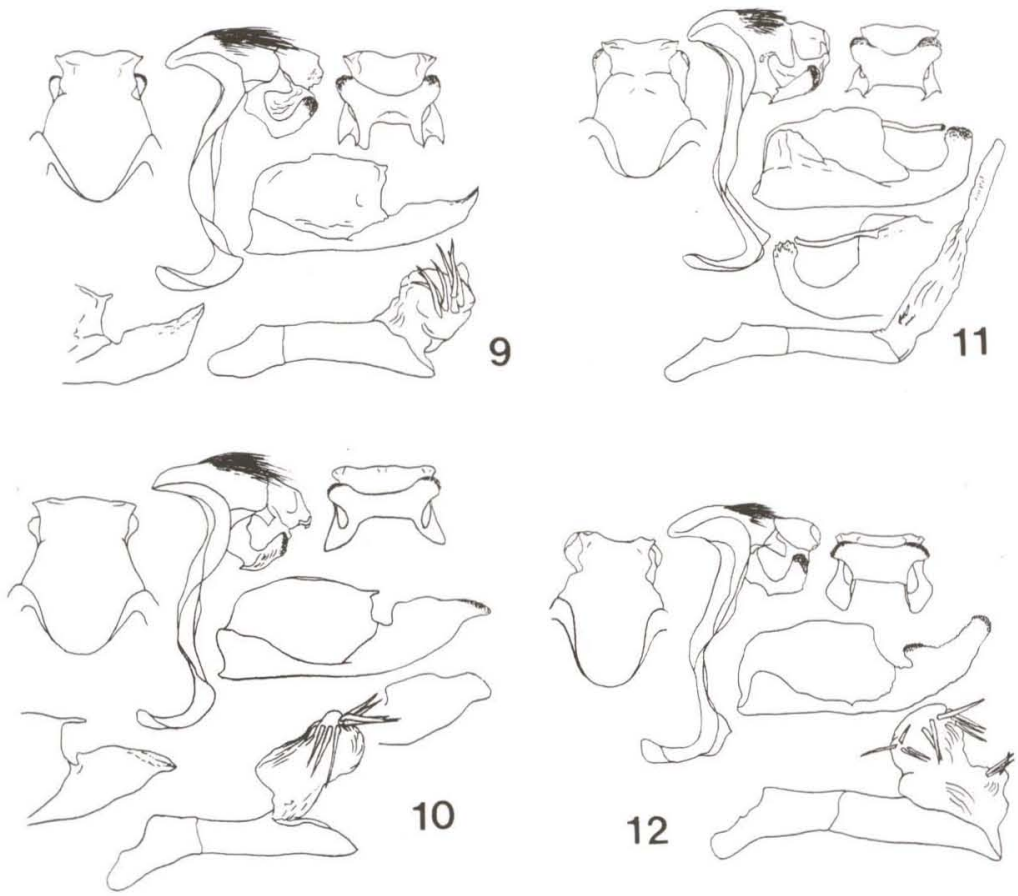

Figs 9-12. Male genitalia of Cephise including lateral and dorsal views of tegumen, gnathus, uncus and associated structures; ventral view of uncus and gnathos; interior view of right valva; left lateral view of aedeagus; and other views of valva as noted. (9) C. cephise, all structures, Brazil: Rondônia (GTA\#1615), interior view of caudal end of right valva, Brazil: Rondônia (GTA \#3543); (10) C. impunctus, all structures including flattened view of caudal end of harpe, Brazil: Rondônia (GTA\#3956), interior view of caudal end of right valva, Brazil: Rondônia (GTA\#2803, holotype); (11) C. glarus, all structures including exterior view of caudal end of right valva, Brazil: Rondônia (GTA\#3689); (12) C. maculatus, all structures, Brazil: Rondônia (GTA\#2652, holotype).

Genitalia - lamella postvaginalis broadly U-shaped; lamella antevaginalis well-sclerotized more or less diamond-shaped with variable central notch on caudal edge, sterigmal plates moderately serrated, usually prominently curved outward caudad; ductus bursae sclerotized Y-shaped caudad becoming membranous and bulbous cephalad where one side partially enclosed by sclerotized plate; corpus bursae as oblong membranous sack.

Distribution and phenology. Cephise cephise is known from Surinam, Brazil (Amazonas, Espírito Santo, Mato Grosso, Rio de Janeiro, Rondônia, Santa Catarina, São Paulo), and Peru (Madre de Dios) and possibly from Bolivia with records for every month (PLÖTZ 1881, SCHAUS 1902, BURNS 1996, this study). It is impossible to know what species EVANS' (1952) records refer to without examination of the specimens. Reports of C. cephise for Mexico and Central America (Evans 1952; FrEEMAN 1970; 

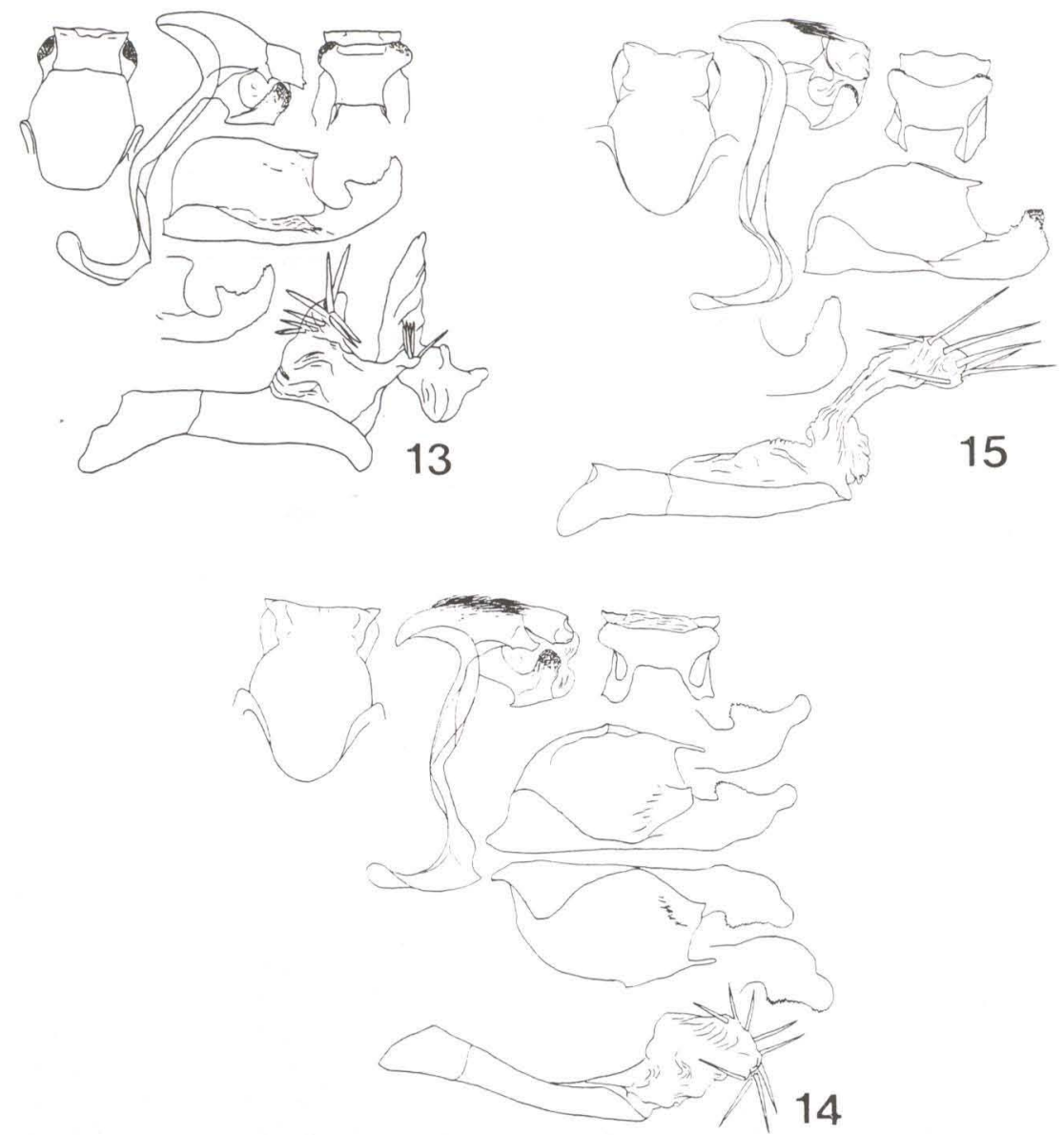

Figs 13-15. Male genitalia of Cephise including lateral and dorsal views of tegumen, gnathus, uncus and associated structures; ventral view of uncus and gnathos; interior view of right valva; left lateral view of aedeagus; and other views of valva as noted. (13) C. burnsi, all structures including flattened view of caudal end of harpe, Brazil: Espírito Santo (DZ 4.044, holotype); (14) C. malesedis, all structures including interior view of left valva and flattened views of caudal ends of both valvae, Brazil: Rondônia (GTA\#2777); (15) C. mexicanus, all structures including flattened view of caudal end of right valva, Mexico: Oaxaca (SRS \#4433, holotype).

DE la MaZa \& DE la MaZA 1985, 1993; DE la MaZA \& White 1990, dE LA MaZA et al. 1991) undoubtedly refer to another species (see below). LAMAS (1994) and ROBBINS et al. (1996) questioned the identity of their records of $C$. cephise from Peru and BURNS (1996) questioned the Peru type locality for Nascus orita; Mielke has confirmed the identity of a male of $C$. cephise from Manu. Specimens examined: no data (1 female, not dissected); BrAzIL: Amazonas; Manaus, no date (1 male, OM \#49.975); Espírito Santo; Linhares, 1-9 June 1973 (1 female, DZ \#4.960), 1-6 June 1974 ( 1 male, DZ\#3.507), 30 June 1973 (1 male, DZ\#354); Mato Grosso; Diamantino, 

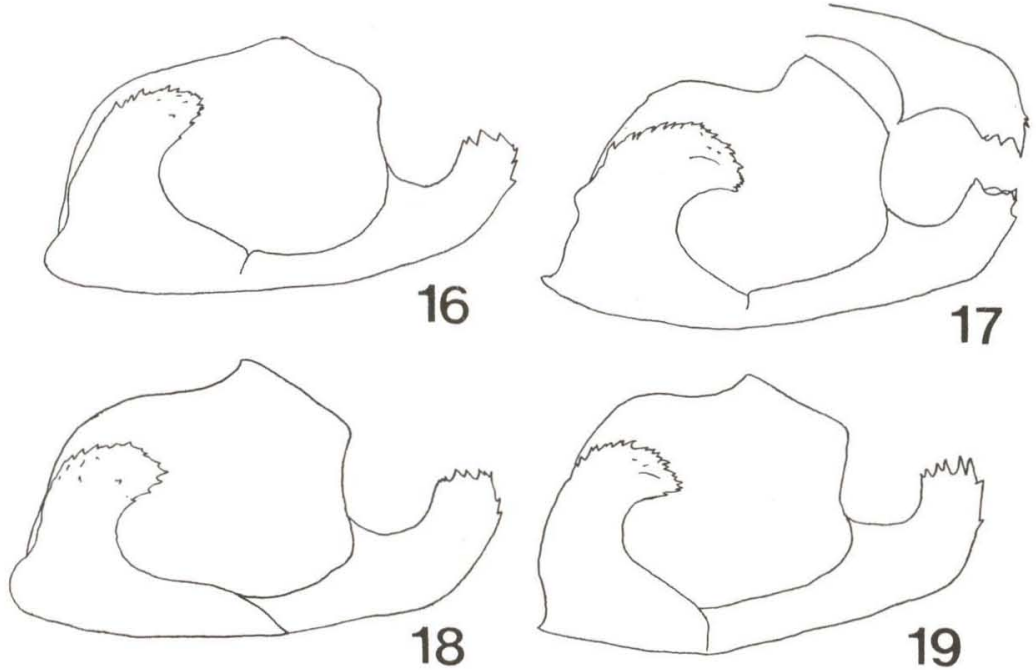

Figs 16-19. Male genitalia of Cephise including interior view of rignt valva. (16) C. callias, Peru: Huáncho (OM \#45.367); (17) C. procerus including interior view of caudal end of left valva, Brazil: Roriama (DZ \#4.019); (18) C. procerus, Brazil: Minas Gerais (OM \#45.159); (19) C. procerus, Brazil: Pará (OM \#9.723).

Fazenda São João, Rio Arinos, 1-8 July 1974 (1 female, DZ \#4.955); Rio de Janeiro; Rio de Janeiro, Barra da Tijuca, 27 July 1965 (1 male, OM \#7.331), Rio de Janeiro, Botafogo, São Clemente, Asilo, 27 Aug. 1961 (1 male, OM \#7.230), Rio de Janeiro, Gavea, 17 Aug. 1958 (1 female, OM \#7.231), Rio de Janeiro, 29 Aug. 1961 (1 male, not dissected), Imbariê, 7 Aug. 1971 (1 male, DZ \#3.535), 9 Aug. 1971 (2 males, not dissected; 2 females, OM \#29.126, one not dissected), 10 Aug. 1972 (2 males, DZ \#3.520, one not dissected), 15 Sept. 1971 (3 males, DZ \#4.030, 3.511, OM \# 29.415), 15 Sept. 1991 (1 male, not dissected), Xerém, Barra de Tinguá, 24 May 1958 (1 male, DZ\#3.536); Rondônia; $62 \mathrm{~km} \mathrm{~S}$ of Ariquemes, Linha C-20, 7 km E of B-65, Fazenda Rancho Grande, 17 June 1993, at paper lures, 1630-1700 (1 male, GTA \#3543), 6 Oct. 1993, at paper lures, 1700-1730 (1 male, GTA \#4054), 13 Nov. 1992, at paper lures, 1600-1630 (1 male, GTA \#2776), 16 Nov. 1992, associated with Eciton burchelli, 1630-1700 (1 male, GTA \#2778), 16 Nov. 1994, at paper lures, 1700-1730 (1 male, not dissected), 21 Nov. 1991 (1 male, OM \#28.265), 3 Dec. 1991, associated with Eciton burchelli at twilight (1 male, GTA \#1615); Santa Catarina; Joinvile, Rio da Prata, 1 May 1980 (5 males, OM \#29.138, 29.475, 3 not dissected; 3 females, OM \#29.325, 29.391, 29.469), Joinvile, 22 Dec. 1981 (1 female, OM \#29.193), São Bento do Sul, Rio Natal, 500m, 4 Mar. 1989 (1 male, OM \#45.351), São Bento do Sul, Rio Vermelho, 850m, 21 Apr. 1983 (1 male, OM \#29.192), Seara, Nova Teutônia, Jan. 1969 ( 1 male, OM \#29.367); São Paulo; Teodoro Sampaio, Parque Estadual do Morro do Diabo, 250-500m, 20-23 Feb. 1990 (1 male, DZ \#4.039); lectotypes of E. cephise and T. hydarnes. The holotype male of Nascus orima and holotype female of Nascus orita were illustrated by BURNS (1996). 

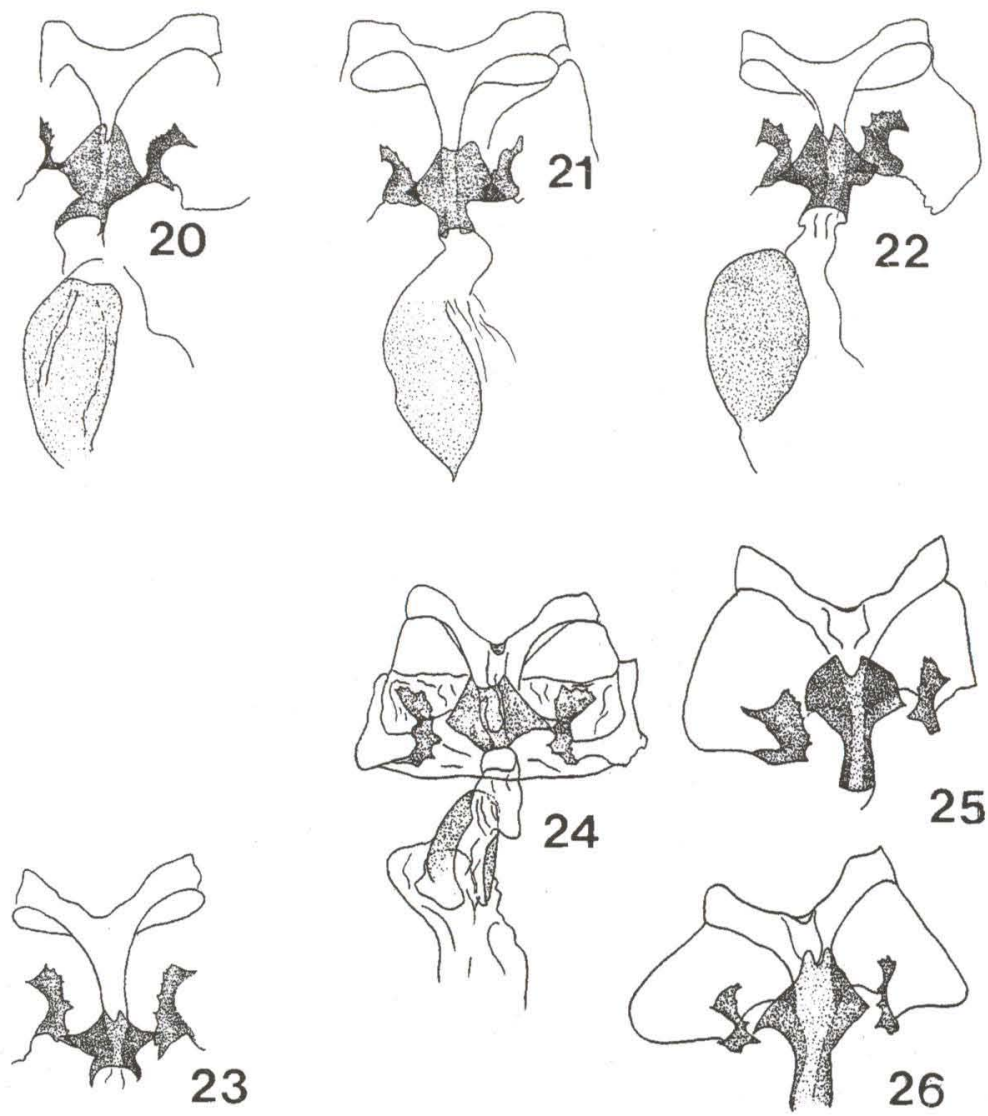

Figs 20-26. Female genitalia of Cephise, ventral view. (20) C. cephise, Brazil: Santa Catarina (OM \#29.391); (21) C. cephise, Brazil: Santa Catarina (OM \#29.325); (22) C. cephise, Brazil: Santa Catarina (OM \#29.193); (23) C. cephise, Brazil: Rio de Janeiro (DZ \#4962); (24) C. impunctus, Brazil: Amazonas (OM dissection, pseudotype of Thymele hydarnes); (25) C. malesedis, Brazil: Santa Catarina (OM \#29.468, allotype); (26) C. malesedis, Brazil: Santa Catarina (OM \#11.619).

Discussion and lectotype designation. The identification of $C$. cephise apparently has been based after the figure in DRAUDT (1922) and after EVANS (1952), especially his drawing of the male genitalia. Eudamus cephise is not the species with a compact forewing macular band, but one with the macule in $\mathrm{M}_{3}-\mathrm{CuA}_{1}$ offset somewhat distad. The male syntype of Eudamus cephise at the BMNH has the following labels: a blue strip -/the genitalia dissected by Evans/; /Type/; green paper - /Cephise. H.S. phocus. Cr./; /compared with Plötz's drawing of cephise H.S./; /Godman-Salvin Coll. 1912.-23. Nascus cephise H.-S./ To fix the identity of the taxon, this specimen is here designated the LECTOTYPE of Eudamus cephise 
Herrich-Schäffer, 1869, and an appropriate label will be added. The genitalia of $C$. cephise are different from those of both $C$. hydarnes (sensu EvANS 1952, described as $C$. malesedis below) and another new species (described as $C$. impunctus below) with the style from the ampulla being very short or absent and the harpe being narrower and more pointed than that of Evans' C. cephise and being upturned slightly caudad and lacking the dorsal process and serrations of Evans' C. hydarnes.

The correct identification of Eudamus cephise now allows evaluation of the names listed in synonymy with $C$. cephise by Evans (1952). Several authors (HAYWARD 1948, EVANS 1952, FREEMAN 1970, BURNS 1996) have misdetermined Thymele hydarnes Mabille, 1877, as a taxon with very different genitalia (see below); the name is a straight synonym of $C$. cephise. The lectotype of $T$. hydarnes is here designated the female syntype at the BMNH with the following labels: white, handwritten - hydarnes P. Mb./ Bresil; round white with a red margin - Type; white, printed - Ex musaeo/ P. Mabille/ 1923; white, printed-R. Oberthür Coll./ Brit. Mus. 1931-136. Telegonus glarus Mabille, 1888, is a species distinct from C. cephise (see below). Nascus orima Schaus, 1902 and Nascus orita Schaus, 1902 (holotypes of both at USNM and illustrated by BURNS 1996), are synonymized with C. cephise herein. BURNS (1996) recently showed that $C$. orima was indeed a recognizably different species from his and EVANS' (1952) concept of $C$. hydarnes and not a synonym of that taxon as treated by EVANS (1952). The male holotype of $N$. orima is virtually identical with the lectotype of $E$. cephise. The female holotype of $N$. orita also seems to be of the $C$. cephise concept based on its general wing shape and the placement of macules. Types no longer exist for Eudamus zopyrus Plötz, 1881, or for Thymele maneros Mabille, 1883. The Plötz manuscript plate for E. zopyrus indicates a female with the placement of macules as on C. cephise; the plate in DRAUDT (1922) depicts an almost identical, perhaps the same, individual. DRAUDT (1922), for some reason, placed Thymele hydarnes as a junior synonym of Thymele zopyrus. It is impossible to tell to what T. maneros referred. MABILLE \& VUILLOT (1891) placed this name as a synonym of Telemiades caepio Herrich-Schaffer, 1869, but Evans (1952) considered the original description to be of $C$. hydarnes. For the sake of stability, Eudamus zopyrus Plötz, 1881, and Thymele maneros, Mabille, 1883 are here synonymized with $C$. cephise and the NEOTYPE of each of these names is designated as the holotype of Nascus orita Schaus, 1902 (the types of all were females). Appropriate labels will be added to that specimen. The final name listed as a synonym of $C$. cephise, Telemiades injuncta Plötz, 1882, was described in synonymy with Telemiades cephise. This is a nomen nudum (ICZN, Art.11.6.); the type (at ZMHB) of this manuscript name is Venada advena (Mabille, 1889).

The figure of Nascus cephise in DRAUDT (1922) is not that species. It may be of the species to be described next as C. impunctus (but see below). It is difficult to decipher Evans' (1952) concept of C. cephise. He undoubtedly examined its type, but may have also examined and included therein material of $C$. impunctus as the genitalia of the two species are similar. His figure of the male genitalia for $C$. cephise is not identifiable. The valva has a style from the ampulla which is longer than seen on C. cephise and of about the length of that on C. impunctus, but the harpe is curved upward as on C. cephise. 


\section{Cephise impunctus Austin \& Mielke, sp.n.}

Figs $5-8,10,24$

Nascus cephise; Draudt, 1922(?).

Description. Male - forewing length $=23.3 \mathrm{~mm}(22.5-24.1, \mathrm{n}=5$; sample from Rondônia); forewing with very long costal fold, apex produced and pointed, termen convex; hindwing broadly convex, produced at tornus into short tail $(2-3 \mathrm{~mm})$; dorsum brown with sparse and inconspicuous ochreous-olive overscaling on forewing base and most of hindwing posterior to vein Rs to within $2 \mathrm{~mm}$ of outer margin; forewing with yellow hyaline macules as follows: subapical in cells $\mathrm{R}_{3}-\mathrm{R}_{4}$ and $\mathrm{R}_{5}-\mathrm{M}_{1}$ (one specimen), in $\mathrm{R}_{5}-\mathrm{M}_{1}$ only (three specimens), or absent (one specimen); discal cell, quadrate, distal edge excavate, proximal edge straight; $\mathrm{M}_{3}-\mathrm{CuA}_{1}$, small triangular, at very base of cell, completely overlapped by macule in discal cell; $\mathrm{CuA}_{1}-\mathrm{CuA}_{2}$, rectangular, slightly excavate on distal edge, very slightly excavate on proximal edge, completely overlapping macules in discal cell and $\mathrm{M}_{3}-\mathrm{CuA}_{1}$, proximal edge in line with proximal edge of macule in discal cell; upper portion of $\mathrm{CuA}_{2}-2 \mathrm{~A}$, small, triangular to ovate, nearly completely overlapped by macule in $\mathrm{CuA}_{1}-\mathrm{CuA}_{2}$; hindwing with very faint traces of dark postmedial and postbasal bands anteriorly; fringe of forewing brown, pale gray towards tornus; fringe of hindwing white, brown at tornus, prominently checkered with black at vein tips.

Ventral surface relatively uniform brown; forewing paler gray-brown along anal margin; hyaline macules as on dorsum, no costal macules; hindwing overscaled centrally with ochreous becoming olive basad with continuous, but very vague, darker postmedial band; vague and ill-defined whitish macule distad of postmedial band in cell $\mathrm{CuA}_{2}-2 \mathrm{~A}$.

Head brown with scattered ochreous scales, whitish to pale yellowish around eyes, palpi mixed gray and ochreous, antennae black on dorsum, ochreous distad on venter, this color extending to sides at segments, nudum red-brown with 23 ( $\mathrm{n}=$ 2), $24(n=1)$, or $25(n=2)$ segments; thorax brown with many ochreous-olive scales on dorsum, fewer on venter, legs brown proximad, ochreous-orange distad; dorsal abdomen brown, ventral abdomen gray-brown with narrow pale yellow to whitish lines laterad.

Genitalia - uncus broad, undivided, pointed distad in dorsal view; gnathos well-developed, caudal ends free, joined cephalad in broad curved shelf; valvae symmetrical, ampulla-costa broad, more or less rectangular, not separable, long style on ampulla, caudal edge of ampulla slightly concave, harpe relatively broad, dorsal margin convex and twisted inward, caudal end turned ventrad and rounded when viewed flattened; aedeagus shorter than valva, stout, cephalad end truncate in lateral view, caudal end blunt, cornuti of 6-7 robust spikes, these all straight.

Female - similar to male; wings broader and more rounded, macules white, three subapical macules present, less extensive overscaling, extensive white towards apex on ventral hindwing adjacent to fringe, ventral hindwing postmedial band broader and more distinct.

Genitalia - lamella postvaginalis broadly U-shaped; lamella antevaginalis well-sclerotized, somewhat spade-shaped with U-shaped central notch on caudal 
edge, sterigmal plates moderately serrated, constricted centrally, not prominently curved outward; ductus bursae sclerotized $Y$-shaped caudad becoming membranous and bulbous cephalad where one side partially enclosed by sclerotized plate.

Types. Holotype male with the following labels: white, printed - BRASIL: Rondonia/ $65 \mathrm{~km}$ S Ariquemes/ linea C-20, $10 \mathrm{~km}$ E/ B-65, $3 \mathrm{~km}$ EFazenda/ Rancho Grande, lot 18/ 22 November 1992/ leg. G. Bongiolo/ at paper lures/ 1630-1700; white, printed and handprinted - Genitalia Vial/ GTA - 2803; red, printed HOLOTYPE/ Cephise impunctus/ Austin \& Mielke. Allotype female: BRAZIL: Espírito Santo; Linhares, 26 May 1974, leg. C. Elias (DZ \#4.963). Paratypes: BRAZIL: Rondônia; $62 \mathrm{~km} \mathrm{~S}$ of Ariquemes, Linha C-20, 7 km E of B-65, Fazenda Rancho Grande, 19 Aug. 1993, at paper lures, 1800 (1 male, GTA \#4156), 20 Aug. 1993, at paper lures, 1730-1800 (1 male, GTA \#3956); Linha C-10, $10 \mathrm{~km} \mathrm{~W}$ of B-65, 21 Oct. 1989 (1 male, GTA \#824), 7 Nov. 1993 (1 male, GTA \#7528). The holotype and allotype are deposited at the Departamento de Zoologia, UFPC.

Type locality. BRAzIL: Rondônia; 62 kilometers south of Ariquemes, Linha C-20, 10 kilometers (by road) east of route B-65, 3 km E of Fazenda Rancho Grande, 180 meters. This is approximately $8 \mathrm{~km}$ northeast of Cacaulândia in typical lowland tropical rainforest. The types from Rondônia were taken in the late afternoon while studying butterfly relationships with army ants.

Etymology. The name refers to the absence of a dark macule within the hyaline band of macules on the forewing.

Distribution and phenology. Cephise impunctus is known from Brazil (Amazonas, Espírito Santo, Rondônia) with records in May, August, October, and November (this study). Specimens examined: types; BRAZIL: Amazonas (pseudotype of $T$. hydarnes, see below). Only careful comparisons and dissections will allow correct identification of the several species of Cephise now known to exist and only then can their distributions be elaborated.

Diagnosis and discussion. The phenotype of $C$. impunctus has the forewing discal series as a compact band including the macule in $\mathrm{M}_{3}-\mathrm{CuA}_{1}$ and leaving no brown area at the base of that cell. This appears to be a constant and nearly unique character of $C$. impunctus as all specimens examined of both sexes are similarly marked. BURNS (1996) noted that his illustrated female of Cephise guatemalaensis (Freeman, 1977) was the only one of this genus that he saw which lacked a brown area at the base of forewing cell $\mathrm{M}_{3}-\mathrm{CuA}_{1}$. On some Cephise nuspesez Burns, 1996, this macule nearly reaches the base of the cell and may account, in part, for some of the distribution records for C. impunctus (as C. cephise) outlined by Evans (1952).

A male illustrated by DraUdT (1922) as Nascus cephise resembles C. impunctus, but appears to represent a Venada advena (Mabille, 1889), and probably has led to misidentification of these taxa (e.g., Evans 1952). Venada advena has markings very similar to $C$. impunctus and may initially be identified as such, but the genitalia are very different.

A female Cephise at ZMHB, labelled / Origin. / Massauary Hhl / hydarnes Mab./, is a pseudotype of Thymele hydarnes and is actually a female of C. impunctus. An appropriate label will be added to this specimen. 


\section{Cephise glarus (Mabille, 1888), sp. reval.}

Figs $11,27,28$

Telegonus glarus Mabille, 1888 (TL: Amazone inférieur [Pará, Brazil], male type at ZMHB, herein designated as the lectotype).

Nascus glarus; Draudt, 1922.

Description. Male - forewing length $=23.0 \mathrm{~mm}(\mathrm{n}=1)$; forewing with very long costal fold, apex produced and pointed, termen slightly convex; hindwing narrow, produced at tornus into short tail $(3 \mathrm{~mm})$, termen slightly convex; dorsum dark brown with heavy red-ochre overscaling on forewing base extending nearly to macules and on most of hindwing posterior to vein Rs to within $2 \mathrm{~mm}$ of outer margin; forewing with very pale yellow hyaline macules as follows: subapical in cells $R_{3}-R_{4}$ and $R_{5}-M_{1}$, both small, anterior slightly smaller than posterior; discal cell, quadrate, distal and proximal edges slightly excavate; $\mathrm{M}_{3}-\mathrm{CuA}_{1}$, more or less quadrate, not quite reaching base of cell leaving a small brown triangular area there, separated distad by about its width from discal cell macule; $\mathrm{CuA}_{1}-\mathrm{CuA}_{2}$, quadrate, deeply excavate on distal edge, very slightly concave on proximal edge, completely overlapping macule in discal cell and contiguous with macule in $\mathrm{M}_{3}-\mathrm{CuA}_{1}$, proximal edge in line with proximal edge of macule in discal cell; upper portion of $\mathrm{Cu}_{2}-2 \mathrm{~A}$, more or less round, completely overlapped by macule in $\mathrm{CuA}_{1}-\mathrm{CuA}_{2}$; hindwing with traces of dark postmedial and postbasal bands anteriorly; fringe of forewing dark gray, white towards tornus; fringe of hindwing white, brown at tornus, prominently checkered with black at vein tips.

Ventral surface relatively uniform brown; forewing paler gray along anal margin; hyaline macules as on dorsum, no costal macules; hindwing lightly overscaled with ochreous and with vague and continuous darker postmedial band; no pale macule distad of postmedial band in cell $\mathrm{CuA}_{2}-2 \mathrm{~A}$.

Head brown with scattered ochreous scales, whitish around eyes, palpi mostly pale gray, antennae black on dorsum, ochreous distad on venter, nudum pale red-brown, 24 segments $(n=1)$; thorax brown heavily overscaled with red-ochre on dorsum, less overscaled on venter, legs brown proximad, ochreous-orange distad; dorsal abdomen brown, gray at segments, overscaled with red-ochre especially anteriorly, ventral abdomen charcoal-gray with few pale yellow scales.

Genitalia - uncus broad, undivided, blunt distad in dorsal view; gnathos well-developed, caudal ends free, joined cephalad in broad curved shelf; valvae symmetrical, ampulla-costa broad, somewhat trapazoidal, not separable, very long style on ampulla curved inward at its caudal end, caudal edge of ampulla more or less straight, cephalad end of sacculus produced far dorsad, harpe narrow, curved upward distad to blunt and spiculose caudal end; aedeagus slightly longer than valva, slender, cephalad end gradually tapering in lateral view, caudal end blunt, cornuti of four small spikes.

Figs 27-34. (27-28) Cephise glarus male, dorsal and ventral, Brazil: Rondônia; Cacaulândia, Fazenda Rancho Grande, 7 km E B-65, linha C-20, 62 km S Ariquemes, 16 Aug. 1993; (29-30) C. malesedis male, dorsal and ventral, holotype; (31-32) C. malesedis female, dorsal and ventral, allotype; (33-34) C. maculatus male, dorsal and ventral, holotype. 

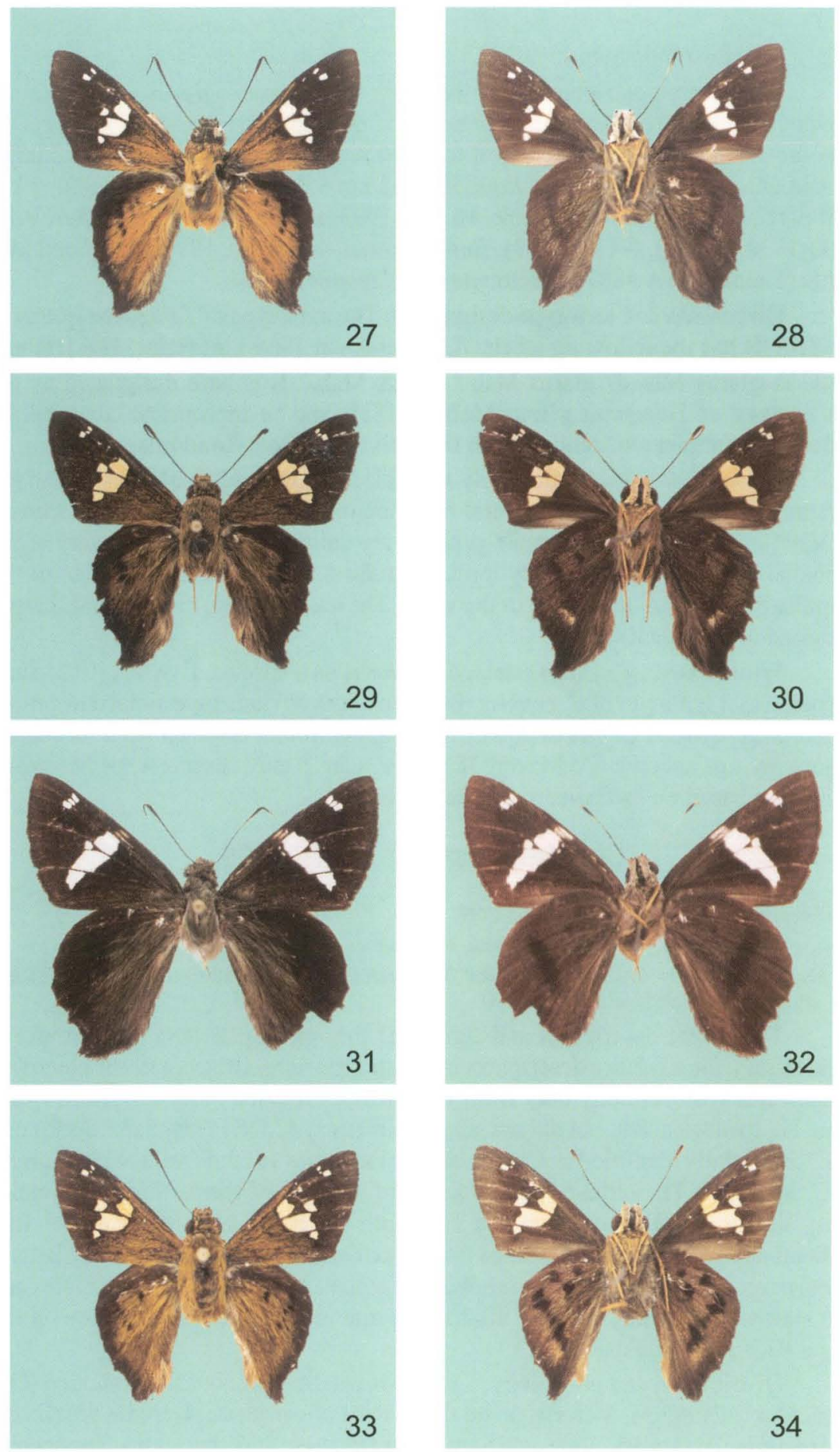

Revta bras. Zool. 17 (3): 757 - 788, 2000 
Female - unknown.

Distribution and phenology. The type of Telegonus glarus was taken somewhere in the lower Amazon drainage. The only specimens known with precise data are from Rondônia, Brazil and taken in August and November (this study). Specimens examined: BrAZIL: Rondônia; 62 km S Ariquemes, Linha C-20, 7 km E of B-65, Fazenda Rancho Grande, 16 Aug. 1993, associated with Eciton burchelli, 1700-1730 (1 male, GTA \#3689); same location, 4-16 Nov. 1997, at UV and MV lights (1 male, GTA \#8876); lectotype of Telegonus glarus.

Discussion and lectotype designation. The male type of Telegonus glarus at the ZMHB has the following labels: /Origin./ Amaz.[onas] inf.[erior] Hhl [Hahnel leg.]/ T. glarus Mb. ơ/ glarus Mab./ Glarus Mab./. It is here designated as the LECTOTYPE of Telegonus glarus Mabille, 1888, and an appropriate label will be added. Its genitalia are identical with the individuals from Rondônia.

Cephise glarus is immediately recognized by its reddish overscaling on the dorsum. The placement of the central forewing macules approximates that seen on C. cephise. The valvae of the male genitalia are unique. The sacculus is very broad cephalad. The style is extremely long, protruding beyond the caudal edge of the ampulla by about $1 / 3$ the length of the valva. The harpe is long, narrow, and sharply upturned in its caudal $1 / 2$.

While DraudT (1922) retained C. glarus as a species, Evans (1952) sunk the name as a synonym of $C$. cephise. Because of the obvious superficial and genital differences between $C$. glarus and $C$. cephise, the former is raised from its current synonymy to a specific level taxon. In fact, $C$. glarus may deserve a species group of its own based on its distinctive male genitalia.

\section{Cephise nuspesez Burns, 1996}

Cephise cephise; Freeman, 1970; Warren 1999.

Cephise cephise cephise; de la Maza \& White, 1990 (in part?).

Cephise nuspesez Burns, 1996 (TL: Costa Rica: Guanacaste Prov., Guanacaste Conservation Area, Santa Rosa Sector, male holotype at USNM).

The recent description and figures of this species (BURNS 1996) make it unnecessary for a further description or illustration here. BURNS (1996) identified this species with certainty only from Guanacaste Province in northwestern Costa Rica. He suspected that, but did not see, specimens at AMNH from San Luis Potosi, Mexico, initially identified as C. cephise (see FREEMAN 1970; WARREN 1999), were of $C$. nuspesez. These have been reexamined and two of them, along with males from Veracruz and Oaxaca in the Escalante collection at AME, are the first authenticated records of $C$. nuspesez from Mexico. They are as illustrated by BURNS (1996) except that there is a single subapical macule (in $\mathrm{R}_{5}-\mathrm{M}_{1}$ ) on three males and two subapical macules $\left(\left(\mathrm{R}_{3}-\mathrm{R}_{4}, \mathrm{R}_{5}-\mathrm{M}_{1}\right)\right.$ on one male instead of the three on the Costa Rican individuals.

Distribution and phenology. Cephise nuspesez is known from Mexico (Oaxaca, San Luis Potosi, Veracruz) and Costa Rica (Guanacaste, Heredia provinces) and recorded in January, June, and September (BuRNS 1996, this sudy). The species 
is to be expected at other Central American locales. Specimens examined: MEXICO: San Luis Potosi; Valles, 13 June 1969 (1 male, SRS \#4366), 20 June 1969 (1 male, GTA \#7930); Veracruz; Presidio (1 male, SRS \#4428); Oaxaca; Chimalapa (1 male, SRS \#4432); CosTa RicA: Heredia Prov.; Sarapique, La Selva, 50m, 1 Sept. 1987 (1 female, GTA \#7929). BURNS (1996) illustrated the holotype and paratypes from Costa Rica.

\section{Cephise malesedis Austin \& Mielke, sp.n.}

Figs $14,25,26,29-32$

Nascus hydarnes; Hayward, 1948.

Cephise cephise hydarnes; Evans, 1952; syn.: maneros, orima.

Cephise hydarnes; Burns, 1996.

Description. Male - forewing length $=22.2 \mathrm{~mm}(21.7-23.0, \mathrm{n}=2$ from Rondônia, 1 from Bolivia); forewing with very long costal fold, apex produced, pointed, termen convex; hindwing narrow, termen slightly convex, produced at tornus into short tail $(2 \mathrm{~mm})$; dorsum brown with yellow-ochre overscaling on forewing base extending distad nearly to macules and on most of hindwing posterior to vein Rs extending to within $2 \mathrm{~mm}$ of outer margin; forewing with yellow hyaline macules as follows: subapical in cells $\mathrm{R}_{3}-\mathrm{R}_{4}, \mathrm{R}_{4}-\mathrm{R}_{5}$, and $\mathrm{R}_{5}-\mathrm{M}_{1}$, central smallest, posterior largest; discal cell, quadrate, distal edge excavate, proximal edge straight to slightly concave; $\mathrm{M}_{3}-\mathrm{CuA}_{1}$, small, triangular to trapazoidal, not reaching base of cell leaving a small brown triangular area there, not or barely overlapping macule in discal cell; $\mathrm{CuA}_{1}-\mathrm{CuA}_{2}$, rectangular, distal edge slightly concave, proximal edge slightly concave to slightly convex, completely overlapping macule in discal cell and nearly completely overlapping macule in $\mathrm{M}_{3}-\mathrm{CuA}_{1}$, proximal edge in line with or extending slightly basad of proximal edge of macule in discal cell; upper portion of $\mathrm{CuA}_{2}-2 \mathrm{~A}$, small, quadrate to more or less oval, nearly completely overlapped by macule in $\mathrm{CuA}_{1}-\mathrm{CuA}_{2}$; hindwing with faint traces of dark postmedial and postbasal bands anteriorly; fringe of forewing gray-brown; fringe of hindwing white, brown at tornus, prominently checkered with black at vein tips.

Ventral surface relatively uniform brown; forewing paler brown along anal margin; hyaline macules as on dorsum; few yellow scales in cell Sc-R1 anterior to discal cell macule; hindwing lightly overscaled with ochreous; very faint continuous darker postmedial band; indistinct and ill-defined white to pale yellow macule distad of postmedial band in cell $\mathrm{CuA}_{2}-2 \mathrm{~A}$.

Head brown with scattered ochreous scales, pale yellowish around eyes, palpi gray with a few pale ochreous scales, antennae black on dorsum, ochreous distad on venter, this color extending to sides at segments especially proximad, nudum red-brown, $22(n=1), 23(n=1)$, or $25(n=1)$ segments; thorax brown with many ochreous scales on dorsum, fewer on venter, legs brown proximad, ochreousorange distad; dorsal abdomen brown, paler at segments, ventral abdomen dark gray to gray-brown with narrow pale yellow lines laterad.

Genitalia - uncus broad, undivided, pointed distad in dorsal view; gnathos well-developed, caudal ends free, joined cephalad in broad curved shelf; valvae 
often asymmetrical, ampulla-costa broad, more or less rectangular, not separable, relatively long style on ampulla, caudal edge of ampulla concave, harpe narrow, dorsal margin produced into spiculose dorsal process cephalad, caudal end produced into rounded lobe, this longer on left valva than on right on some individuals; aedeagus slightly shorter than valva, slender, cephalad end truncate in lateral view, caudal end blunt, cornuti of 12 robust spikes.

Female - similar to male; wings broader and more rounded, macules white, less extensive overscaling on both wings, ventral hindwing postmedial band broader and without distinct white distad of its posterior end.

Genitalia - lamella postvaginalis broadly V-shaped; lamella antevaginalis well-sclerotized, diamond to spade-shaped with narrow U-shaped central notch on caudal edge, sterigmal plates moderately serrated, more or less straight; ductus bursae sclerotized Y-shaped caudad becoming membranous and bulbous cephalad where one side partially enclosed by sclerotized plate.

Types. Holotype male with the following labels: white printed - BRASIL: Rondonia/ 62 km S Ariquemes/ linha C-20, 7 km E/ B-65, Fazenda Rancho Grande/ 22 July 1994/ leg. G.T. Austin/ (at paper lures, 1630-1700); white, printed and handprinted - Genitalic Vial/ GTA - 7580; red, printed - HOLOTYPE/ Cephise malesedis/ Austin \& Mielke. Allotype female: BrazIL: Santa Catarina; Joinvile, 22 Sept. 1980 (OM \#29.468). Paratypes: BoliviA: R. Yapacani (E. Bolivia), 600 m, Feb. 1915, J. Steinbach (1 male, GTA \#4179, CM); BRAZIL: Espírito Santo; Santa Teresa, 31 Jan. 1968 (1 male, DZ \#4.034), Linhares, Mar. 1970 (1 male, DZ \#3.523); Mato Grosso; Diamantino, Fazenda São João, 3 Sept. 1979 (1 male, OM \#29.312), Alto Rio Arinos, 22 Jan. 1978 (1 male, OM \#29.379); Rio de Janeiro; Barra de São João, 1 Mar. 1974 (1 male DZ \# 4.035), Imbariê, 150m, 13 Jan. 1965 (1 male, DZ \#4.033); Rondônia; 62 km S Ariquemes, Linha C-20, 7 km E of B-65, Fazenda Rancho Grande, 28 Oct. 1997, at paper lures, 1600-1630 (1 male, GTA \#8877), 13 Nov. 1992, at paper lures, 1530-1600 (1 male, GTA \#2777); Santa Catarina; Joinvile, no date (1 female, OM \#11.619), 16 Jan. 1987 (1 male, not dissected), 7 Feb. 1993 (1 male, not dissected), 20 Feb. 1974 (1 female, not dissected), 22 Feb. 1969 (1 male, OM \#29.175), 30 June 1977 (1 male, not dissected), 14 Sept. 1966 (1 male, not dissected), 27 Dec. 1981 (1 male, not dissected), 29 Dec. 1993 (1 male, OM \#37.552), Joinvile, Rio da Prata, 1 May 1980 (1 male, OM \#29.168), Seara, Nova Teutônia, Nov. 1961 (1 male, OM \#29.169). The holotype, allotype, and all except two paratypes are deposited at the Departamento de Zoologia, UFPC. One paratype is at CM and the other will be retained at the NSM.

Type locality. BRAZIL: Rondônia; 62 kilometers south of Ariquemes, Linha C-20, 7 kilometers (by road) east of route B-65, Fazenda Rancho Grande, 180 meters. This is approximately $5 \mathrm{~km}$ northeast of Cacaulândia in typical lowland tropical rainforest. The types from Rondônia were taken in the late afternoon while studying butterfly relationships with army ants.

Etymology. The name means misplaced, a reflection of this species being identified as $C$. hydarnes by several authors. 
Distribution and phenology. Cephise malesedis is known to occur in the southern half of Brazil (Espírito Santo, Mato Grosso, Minas Gerais, Rio de Janeiro, Rondônia, Santa Catarina, São Paulo), Bolivia, Argentina (Misiones), and Paraguay; material has been seen from all months except April and August (HAYWARD 1948; Evans 1952; Brown \& Mielke 1967; Burns 1996, this study). Specimens examined: types. BuRns (1996) illustrated a male (as C. hydarnes) from Paraguay.

Discussion. Cephise malesedis is the phenotype considered by Evans (1952) to be Thymele hydarnes. That taxon was synonymized with $C$. cephise above. The female lectotype of $T$. hydarnes has no abdomen, but is not considered to be the species named here as $C$. malesedis for the following reasons: the subapical macules are smaller than on $C$. malesedis; the hindwing termen of $T$. hydarnes abruptly curves to a moderately developed tornal lobe exactly as on the holotype of $C$. orita, also synonymous with C. cephise (see photographs in BuRNS 1996) (termen not prominently curved on C. malesedis and lobe shorter); and the white of the ventral hindwing fringe extends well onto the wing surface proper again as on the holotype of $C$. orita (no white on the wing proper on $C$. malesedis). The female of $C$. impunctus has a compact forewing band, has some white on the hindwing adjacent to the fringe, and an even more rounded hindwing and shorter tornal lobe than does C. malesedis.

The superficial appearance and genitalia of the specimens of C. malesedis examined are nearly identical to the male from Paraguay illustrated by BURNS (1996) who identified this as C. hydarnes after HAYWARD (1948) and EVANS (1952), both of whom also illustrated the genitalia under that name. BURNS (1996) pointed out that these determinations, including his, may be incorrect since the type of $T$. hydarnes is a female and there were no known associated pairs. With the identification of the type of $T$. hydarnes at the BMNH and its synonymy with $C$. cephise (see above), it is obvious that these recent identifications of $C$. hydarnes are spurious and actually refer to C. malesedis. A male from Pará (Brazil) mentioned by Evans (1952) as "intermediate to hydarnes" may well represent another species, perhaps undescribed. BURNS (1996) mentioned, but did not illustrate, the asymmetrical valvae on many (most?) individuals of this species. These are illustrated here.

\section{Cephise maculatus Austin \& Mielke, sp.n.}

Figs $12,33,34$

Description. Male - forewing length $=20.2 \mathrm{~mm}$; forewing with very long costal fold, apex produced, more or less pointed, termen convex; hindwing narrow, termen slightly convex, produced at tornus into short tail $(2 \mathrm{~mm})$; dorsum brown with prominent yellow-ochre overscaling on forewing base extending distad to macules and on most of hindwing posterior to vein Rs to within $2 \mathrm{~mm}$ of outer margin; forewing with deep yellow hyaline macules as follows: subapical in cells $\mathrm{R}_{3}-\mathrm{R}_{4}, \mathrm{R}_{4}-\mathrm{R}_{5}$, and $\mathrm{R}_{5}-\mathrm{M}_{1}$, central one smallest, posterior one largest; discal cell, quadrate, distal edge excavate, proximal edge straight; $\mathrm{M}_{3}-\mathrm{CuA}_{1}$, small quadrate, not reaching base of cell by its width leaving brown triangular area there, separated distad from discal cell by more than $1 / 2$ its width; $\mathrm{CuA}_{1}-\mathrm{CuA}_{2}$, rectangular, excavate 
on distal edge, slightly convex on proximal edge, completely overlapping macule in discal cell and proximal part of macule in $\mathrm{M}_{3}-\mathrm{CuA}_{1}$, proximal edge in line with proximal edge of macule in discal cell; upper portion of $\mathrm{CuA}_{2}-2 \mathrm{~A}$, small, quadrate, nearly completely overlapped by macule in $\mathrm{CuA}_{1}-\mathrm{CuA}_{2}$; hindwing with faint traces of dark postmedial (entire) and postbasal (anterior only) bands; fringe of forewing gray-brown; fringe of hindwing gray-brown, paler gray posteriorly, brown at tornus.

Ventral forewing brown, paler gray-brown along outer and anal margins, ochreous scales in crease of discal cell, hyaline macules as on dorsum, no costal macules; hindwing red-brown except for brown anal margin, overscaled centrally with ochreous, this yellower and most prominent distad to postmedial band in cell $\mathrm{CuA}_{2}-2 \mathrm{~A}$, darker brown postmedial and postbasal bands macular.

Head brown with many ochreous scales, pale yellow around eyes, palpi gray-brown with pale ochreous scales, antennae black, white at segments proximad, nudum pale red-brown, 24 segments $(n=2)$; thorax with many ochreous scales on dorsum, browner on venter, legs brown proximad, ochreous-orange distad; dorsal abdomen brown, ventral abdomen mixed dark brown and yellow-ochre.

Genitalia - uncus broad, undivided, blunt distad in dorsal view; gnathos well-developed, caudal ends free, joined cephalad in broad curved shelf; valvae symmetrical, ampulla-costa moderately broad, more or less rectangular, not separable, no style on ampulla, caudal edge of ampulla concave, harpe narrow, dorsal margin produced into spiculose dorsal process cephalad, caudal end elongate to rounded lobe; aedeagus slightly longer than valva, stout, cephalad end somewhat truncate in lateral view, caudal end gradually tapering, cornuti as 13 spikes of variable size.

Female - unknown.

Types. Holotype male with the following labels: white, printed - BRAsIL: Rondonia/ 65 km S Ariquemes/ linea C-20, 7 km E/ B-65, Fazenda/ Rancho Grande/ 19 November 1992/ leg. G. T. Austin/ at paper lures/1430-1500; white, printed and handprinted - Genitalic Vial/ GTA - 2652; red, printed - HOLOTYPE/ Cephise maculatus/ Austin \& Mielke. Paratype: BRAzIL: Rondônia; 65 km S Ariquemes, Linha C-20, 7 km E of B-65, Fazenda Rancho Grande, 12 Nov. 1994, at paper lures, 1600-1630 (1 male, GTA \#6620). The holotype is deposited at the Departamento de Zoologia, UFPC.

Type locality. BRAzIL: Rondônia; 62 kilometers south of Ariquemes, Linha C-20, 7 kilometers (by road) east of route B-65, Fazenda Rancho Grande, 180 meters. This is approximately $5 \mathrm{~km}$ northeast of Cacaulândia in typical lowland tropical rainforest. The types were taken in mid to late afternoon while studying butterfly relationships with army ants.

Etymology. The species is named after the hindwing postmedial band composed of separated macules on males compared to the more continuous nature of this band on other known species of Cephise.

Distribution and phenology. Cephise maculatus is known only from Rondônia in western (Rondônia) Brazil, with both records for November (this study). Specimens examined: types. 
Diagnosis and discussion. The male of C. maculatus is superficially recognized by the macular aspect of the ventral hindwing postmedial band and the broad contrastingly paler margin to the ventral forewing. The dorsum of C. maculatus is similar to those of $C$. cephise and C. malesedis with the central hyaline macules not forming a compact band. The ochreous overscaling of the forewing base and hindwing is somewhat brighter than on either of those two species. The male genitalia are similar to those of $C$. malesedis, but lack a style and the dorsal process and caudal portion of the harpe are longer and symmetrical.

\section{Cephise burnsi Austin \& Mielke, sp.n.}

Figs $13,35-38,43$

Description. Male - forewing length $=19.5-21.6 \mathrm{~mm}$; forewing with very long costal fold, apex produced, more or less pointed, termen convex; hindwing narrow, termen slightly convex, produced at tornus into short tail $(2 \mathrm{~mm})$; dorsum brown with prominent yellow-ochre overscaling on forewing base extending distad to distal edge of macules and on most of hindwing posterior to vein Rs to within $2 \mathrm{~mm}$ of outer margin; forewing with deep yellow hyaline macules as follows: subapical in cells $R_{3}-R_{4}, R_{4}-R_{5}$, and $R_{5}-M_{1}$, central one smallest $(n=3)$ or absent $(n=3)$, posterior one largest; discal cell, quadrate, distal edge excavate, proximal edge nearly straight; $\mathrm{M}_{3}-\mathrm{CuA}_{1}$, small quadrate, not reaching base of cell by nearly its width leaving brown triangular area there, separated distad from discal cell by more than $1 / 2$ its width; $\mathrm{CuA}_{1}-\mathrm{CuA}_{2}$, rectangular, excavate on distal edge, slightly convex on proximal edge, completely overlapping macule in discal cell and most of macule in $\mathrm{M}_{3}-\mathrm{Cu} \mathrm{A}_{1}$, proximal edge in line with proximal edge of macule in discal cell; upper portion of $\mathrm{CuA}_{2}-2 \mathrm{~A}$, small, triangular, nearly completely overlapped by macule in $\mathrm{CuA}_{1}-\mathrm{CuA}_{2}$; hindwing with faint traces of dark postmedial band anteriorly; fringe of forewing gray-brown; fringe of hindwing gray-brown, paler gray posteriorly, brown at tornus.

Ventral forewing brown, paler gray-brown along anal margin, ochreous scales in crease of discal cell, hyaline macules as on dorsum, no costal macules; hindwing brown with slight purple gloss, paler brown anal margin, overscaled centrally with ochreous, broad darker brown postmedial band, narrow and vague postbasal band, both entire.

Head brown with many ochreous scales, pale yellow around eyes, palpi gray-brown with many pale ochreous scales, antennae black, ochre at segments proximad, entirely ochre on ventral surface distad, nudum pale red-brown, 25 segments $(n=1)$; thorax with many ochreous scales on dorsum, brown on venter, legs brown proximad, ochreous-orange distad.

Genitalia - uncus broad, undivided, blunt distad in dorsal view produced to two short points laterad; gnathos well-developed, caudal ends free, joined cephalad in broad curved shelf; valvae symmetrical, ampulla-costa moderately broad, rectangular, not separable, no style on ampulla, caudal edge of ampulla concave and erect, harpe narrow, dorsal margin finely toothed, produced into dorsal processes caudad and cephalad; aedeagus slightly longer than valva, stout, cephalad end short, caudal end slightly tapering and curving ventrad, cornuti as 14 straight spikes of variable size. 
Female - similar to male; wings broader and more rounded, macules white with central macules more closely spaced, less extensive overscaling on both wings, ventral hindwing postmedial band entire.

Genitalia - lamella postvaginalis broadly and shallowly U-shaped; lamella antevaginalis well-sclerotized, more or less diamond-shaped with no central notch on caudal edge, sterigmal plates heavily, but finely, serrated, caudal spine in inner edge long, prominently narrow and curved outward caudad; ductus bursae sclerotized Y-shaped caudad becoming membranous and bulbous cephalad where one side partially enclosed by sclerotized plate.

Types. Holotype male with the following labels: white, printed and handprinted - Linhares.Espírito / Santo, Brasil / 27-vi-1973 / C. Elias leg.; white, printed - DZ \# 4.044; red, printed - HOLOTYPE / Cephise burnsi / Austin \& Mielke. Allotype female: BRAZIL: Rio de Janeiro; Imbariê, 15 Sept. 1981 (OM \#45.359). Paratypes: BrazIL: Espirito Santo; Linhares, 10-15 June 1974 (1 male, not dissected), 2-7 Sept. 1974 (1 male, not dissected), 5 Sept. 1973 (2 males, not dissected); Rio de Janeiro; Rio de Janeiro, Jacarepagua, Três Rios, 23 Jan. 1962 (1 male, OM \#171). The holotype, allotype, and all paratypes are deposited at the Departamento de Zoologia, UFPC.

Type locality. BRAZIL: Espírito Santo; Linhares.

Etymology. It is our pleasure to name this species after John M. Burns who has added much to our knowledge of the taxonomy of hesperiids and wrote a seminal paper on Cephise.

Distribution and phenology. Cephise burnsi is known only from southeastern Brazil (Espírito Santo, Rio de Janeiro) with records for January, June, and September (this study). Specimens examined: types.

Diagnosis and discussion. The male of $C$. burnsi is most similar to $C$. maculatus, but the postmedial band on the ventral hindwing is not divided into individual macules. It is also similar to various other species of the genus, but is easily separated by its genitalia. These are most similar to those of C. malesedis, but $C$. burnsi has a very short style, the lobe on the harpe is triangular rather than rounded, the aedeagus curves ventrad, and there are more cornuti. The sterigmal plates of the female genitalia of $C$. burnsi are more finely serrate than on other Cephise with a very long spine on the caudal (inner) edge.

\section{Cephise mexicanus Austin \& Mielke, new species}

Figs $15,39-42,44$

Cephise cephise; Freeman, 1970 (in part).

Cephise cephise cephise; de la Maza and White, 1990.

Description. Male - forewing length $=21.2 \mathrm{~mm}$ (holotype); forewing with very long costal fold, apex rounded, termen convex; hindwing termen concave, produced at tornus into short tail $(2 \mathrm{~mm})$; dorsum brown with prominent ochreous

Figs (35-42). (35-36) Cephise burnsi male, dorsal and ventral, holotype; (37-38) C. burnsi female, dorsal and ventral, allotype; (39-40) C. mexicanus male, dorsal and ventral, holotype; (41-42) C. mexicanus female, dorsal and ventral, allotype. 

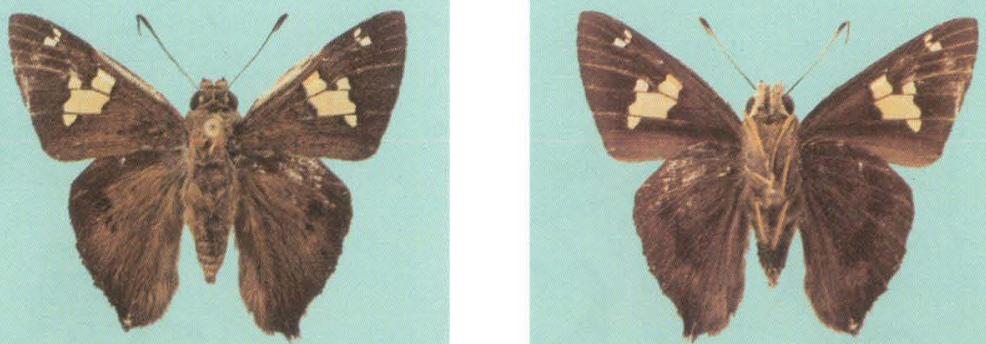

35

36
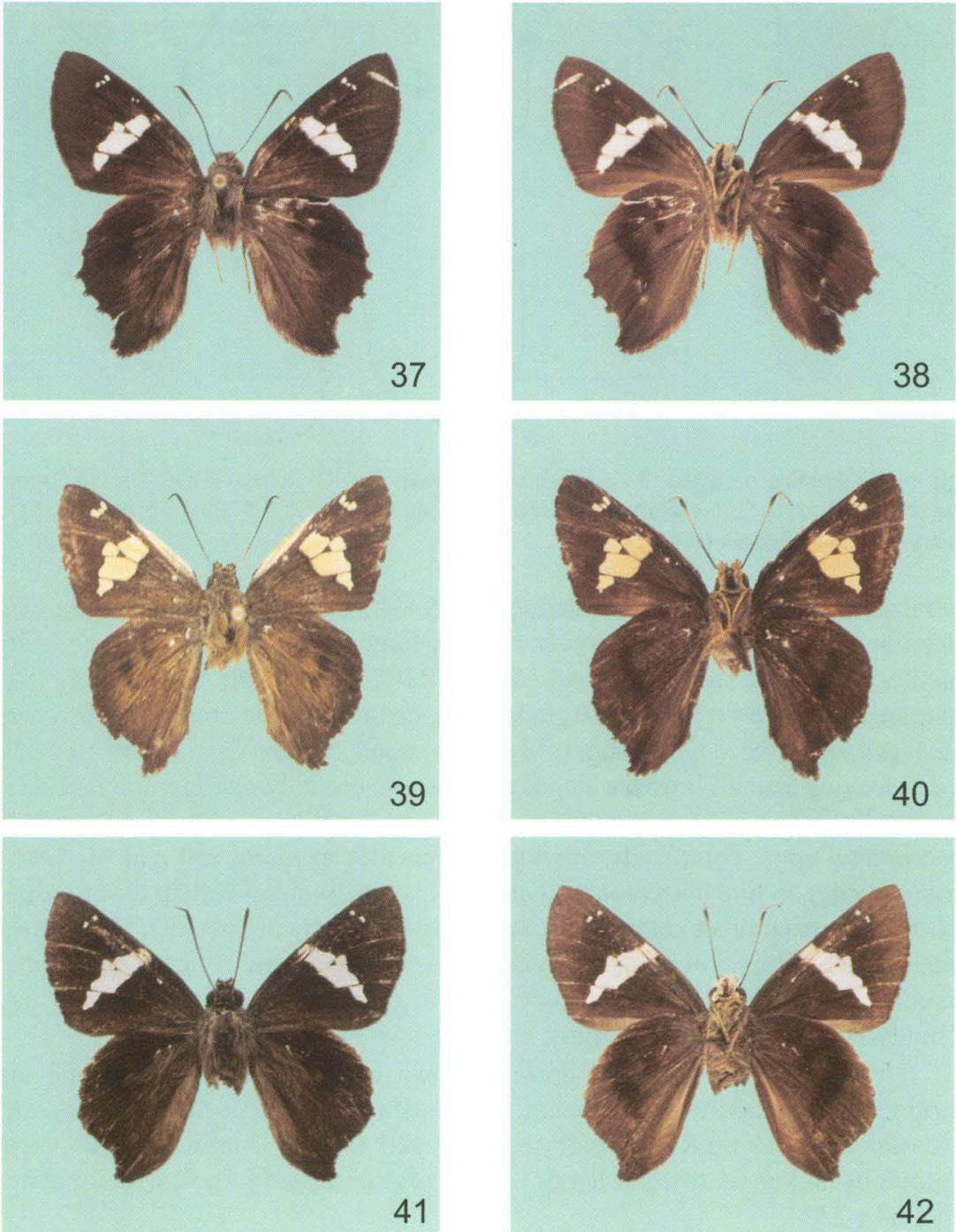

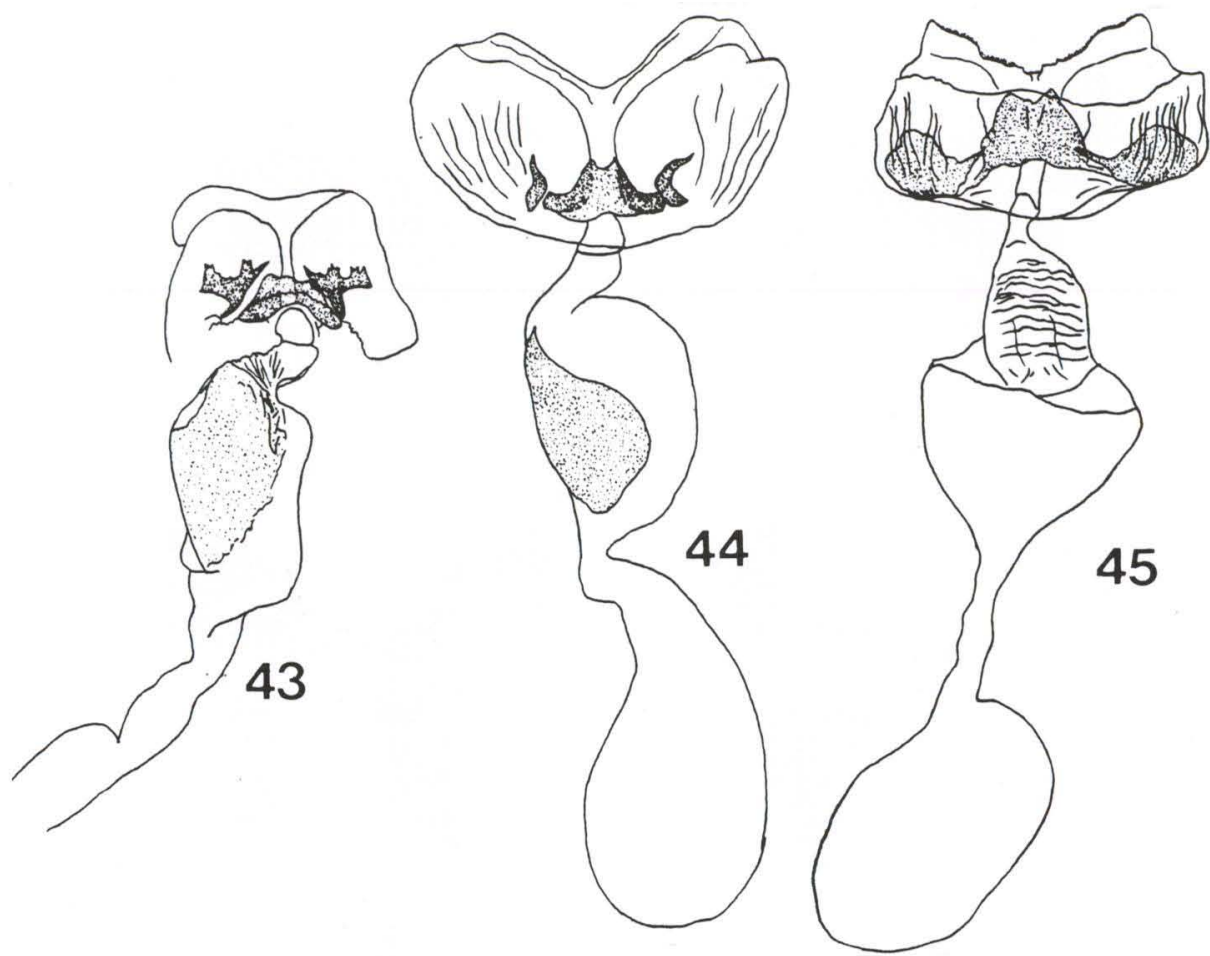

Figs 43-45. Female genitalia of Cephise, ventral view. (43) C. burnsi, Brazil: Rio de Janeiro (OM \#45.359); (44) C. mexicanus, Mexico: San Luis Potosi (GTA \#7931, allotype); (45) C. callias, Brazil: Rondônia (GTA \#7529).

overscaling on forewing base extending nearly to macules and on most of hindwing posterior to vein Rs nearly to outer margin; forewing with deep yellow hyaline macules as follows: subapical in cells $\mathrm{R}_{3}-\mathrm{R}_{4}, \mathrm{R}_{4}-\mathrm{R}_{5}$, and $\mathrm{R}_{5}-\mathrm{M}_{1}$, all relatively large compared to those on species treated above, central macule smaller than others; discal cell, quadrate, edges straight; $\mathrm{M}_{3}-\mathrm{CuA}_{1}$, small, trapazoidal, not reaching base of cell leaving a small brown triangular area there, partially overlapping macule in discal cell; $\mathrm{CuA}_{1}-\mathrm{CuA}_{2}$, rectangular, excavate on distal edge, very slightly convex on proximal edge, completely overlapping macules in discal cell and $\mathrm{M}_{3}-\mathrm{CuA}_{1}$, proximal edge in line with proximal edge of macule in discal cell; anterior portion of $\mathrm{CuA}_{2}-2 \mathrm{~A}$, triangular, completely overlapped by macule in $\mathrm{CuA}_{1}-\mathrm{CuA}_{2}$, posterior distal corner with small attached hyaline dot; hindwing with faint traces of dark postmedial and postbasal bands anteriorly; fringe of forewing gray-brown; fringe of hindwing white, brown at tornus, checkered with black at vein tips.

Ventral surface relatively uniform brown; forewing paler brown along anal margin; hyaline macules as on dorsum; additional vague smudge of yellowish scales in costal cell and $\mathrm{Sc}-\mathrm{R}_{1}$ anterior to discal cell macule; hindwing with vague continuous darker postmedial band; no pale macule distad to postmedial band in cell $\mathrm{CuA}_{2}-2 \mathrm{~A}$. 
Head brown with scattered ochreous scales, pale yellow around eyes, palpi gray with pale ochreous scales, antennae black on dorsum, ochreous distad on venter, this color extending to sides at all segments, nudum red-brown, 22 segments $(\mathrm{n}=1)$; thorax brown with many ochreous scales on dorsum, fewer on venter, legs brown proximad, ochreous-orange distad.

Genitalia - uncus broad, undivided, blunt distad in dorsal view; gnathos well-developed, caudal ends free, joined cephalad in broad curved shelf; valvae symmetrical, ampulla-costa broad, caudal edge convex, not separable, short style on ampulla, caudal edge of ampulla concave, harpe short, broad with caudal end curved upward, blunt, and spiculose; aedeagus prominently longer than valva, broad cephalad and slender caudad, cephalad end truncate in lateral view, caudal end gradually tapering, cornuti of 8 robust spikes.

Female - forewing length $=22.1 \mathrm{~mm}$ (allotype); similar to male but with broader and more rounded wings; dorsum brown with inconspicuous ochreous overscaling at base of forewing, posteriorly on hindwing, and on thorax; forewing macules white and narrower than on male; double costal macule anterior to discal cell macule; two subapical macules (that in $\mathrm{R}_{4}-\mathrm{R}_{5}$ absent); venter as on male except for color and width of macules; hindwing apex with narrow white on wing proximad to fringe.

Genitalia - lamella postvaginalis broadly V-shaped; lamella antevaginalis well-sclerotized more or less triangular with U-shaped central notch on caudal edge, sterigmal plates thin, curved outward caudad, not serrated; ductus bursae sclerotized Y-shaped caudad becoming membranous and bulbous cephalad where one side partially enclosed by sclerotized plate; corpus bursae oval.

Types. Holotype male with the following labels: white, printed and handprinted - T. Escalante/ Chimalapa/ Oax/IX - 56; white, printed - A.C. Allyn/ Acc. 1973-48; white, printed and handprinted -Genitalic Vial/ SRS - 4433; red, printed - Holotype/Cephise mexicanus/ Austin \& Mielke. Allotype female: MEXICO: San Luis Potosi; Valles, 27 June 1968 (GTA \#7931). The holotype is deposited at AME; the allotype is at AMNH.

Type locality. MEXIco: Oaxaca; Chimalapa.

Etymology. The species is named after the only country from which it is known.

Distribution and phenology. Cephise mexicanus is known from Mexico (San Luis Potosi, Oaxaca) with the holotype taken in September and the allotype in June (this study). Specimens examined: types.

Diagnosis and discussion. Superficially, the male of C. mexicanus most closely resembles $C$. cephise, but has broader and deeper yellow macules with that in $\mathrm{M}_{3}-\mathrm{CuA}_{1}$ nearer to the cell base and partly overlapping the discal cell macule. The sympatric C. nuspesez has paler macules and those at the subapex are smaller. The male genitalia of C. mexicanus, with the upturned harpe and short style, do not particularly resemble those of any described species of the genus. The female is likewise similar to that of $C$. nuspesez, but has narrower white at the apex of the ventral hindwing. The genitalia are different from similar species of Cephise with the sterigmal plates lacking serrations. 
The identification and description of a second species of Cephise from Mexico, C. mexicanus, and the verification of the occurrence of $C$. nuspesez for the country (with their occurrence in sympatry in San Luis Potosi and Oaxaca) calls into question the records of $C$. cephise as far north as Chiapas (DE LA MAZA \& DE LA MAZA 1985, 1993; DE LA MAZA et al. 1991) or Honduras (Evans 1952).

\section{"procerus" group}

The species of Cephise here included in the "procerus" group are characterized by the presence of long tails on the hindwing and little sexual dimorphism. BURNS (1996) identified three tailed taxa, previously included in Polythrix (Evans 1952, FrEEMAN 1977), as members of Cephise: Eudamus callias Mabille, 1888; Eudamus anginulus Godman \& Salvin, 1893, and its synonym Eudamus callicina Schaus, 1902; and Polythrix guatemalaensis Freeman, 1977. BuRNS (1996) did not know the identity of other taxa associated with these names by Evans (1952), but these also belong within Cephise (see below). One species of this group was recorded in central Rondônia.

\section{Cephise procerus (Plötz, 1880)}

Figs $17-19,46,47$

Goniurus procerus Plötz, 1880 (TL: Pará, Brazil, male type at ZMHB, herein designated as the lectotype).

Eudamus procerus; Godman, 1907.

Polythrix procerus; Evans, 1952.

Cephise near callias; Burns, 1996.

Cephise procerus; Mielke \& Casagrande, 1998.

BURNS (1996) was unsure of the identity of Goniurus procerus, but recognized that two names synonymized with this species (as Polythrix procerus) by Evans (1952) were Cephise. The type of Goniurus procerus is an undoubted Cephise with the typical structure of the palpi for the genus. The hyaline macule in forewing cell $\mathrm{M}_{3}-\mathrm{Cu} \mathrm{A}_{1}$ is clearly out of line with the remaining macules, barely overlapping the distal corner of the macule in $\mathrm{CuA}_{1}-\mathrm{CuA}_{2}$ and well-separated from the discal cell macule. The distal macule in cell $\mathrm{Sc}+\mathrm{R}_{1}$-Rs on the ventral hindwing is vague. The male type at ZMHB, here designated the LECTOTYPE of Goniurus procerus Plötz, 1880, has the following labels: / 5082 / Type / Progne N. Pará Sieber / procerus PI. type /. This lectotype closely matches the male and female illustrated by BURNS (1996) as $C$. near callias which is here considered to be synonymous with C. procerus. The male and female genitalia were illustrated by BURNs (1996) as $C$. near callias.

Distribution and phenology. Cephise procerus has been reported from Mexico, Guatemala, Honduras, Panama (Canal Zone), French Guiana (Guyane), Venezuela, and Brazil (Pará, Roraima) (Plötz 1880, Evans 1952, FrEEMAN 1979, Mielke \& CASAgRANDE 1991, DE LA MAZA et al. 1991, BuRnS 1996). Some of these may refer to other taxa (e.g., WARREN 1999; see also below); the only certain records are for Panama, Guyane, and Brazil (Minas Gerais, Pará, Roraima) (PLÖTZ 
1880, Mielke \& CaSagrande 1991, Burns 1996, this study). Specimens examined: BrazIL: Minas Gerais; Paracatu, 4 Sept. 1968 (1 male, OM \#45.159), Pará; Óbidos, no date (1 male, OM \#9.723), Roraima; Alto Alegre, Ilha de Maracá, 24-31 Aug. 1987 (1 male, DZ \#4.019); lectotype.
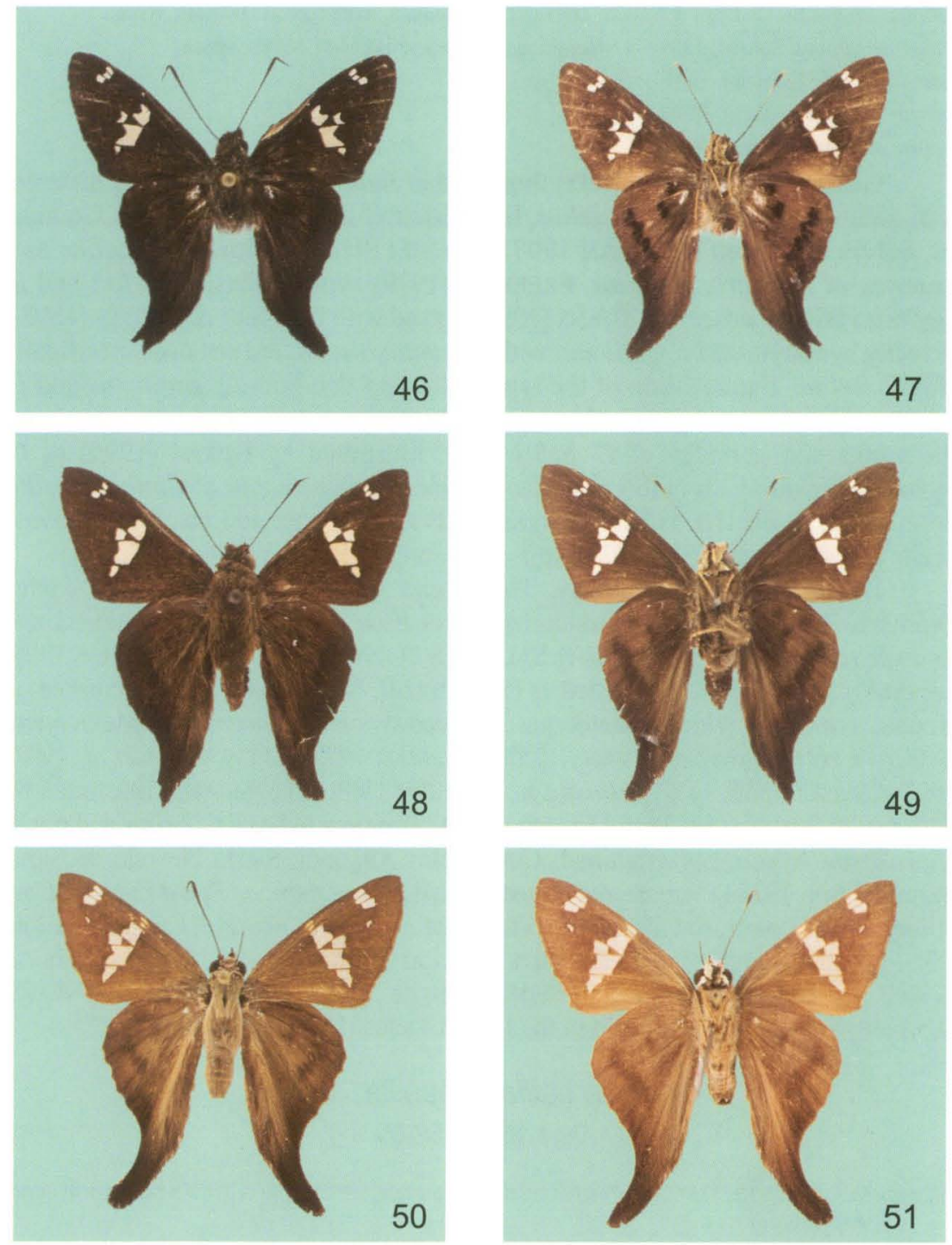

Figs 46-51. (46-47) Cephise procerus male, dorsal and ventral, Brazil: Roraima; Alto Alegre, Ilha de Maracá, 24-31 Aug. 1987; (48-49) Cephise aelius male, dorsal and ventral, Mexico: Quintana Roo; Nuevo X-Can, 30 July 1977; (50-51) C. aelius female, dorsal and ventral, Venezulea: Distrito Federal; Caracas, 31 Jan. 1936. 


\section{Cephise aelius (Plötz, 1880), sp. reval., comb.n.}

Figs 48-51

Goniurus aelius Plötz, 1880 (TL: Pará [Brazil], female type at ZMHB, herein designated as the lectotype).

Eudamus auginulus Godman \& Salvin, 1893 (TL: Guatemala, male type at BMNH); syn.n.

Eudamus callicina Schaus, 1902 (TL: Honduras, female holotype at USNM); syn.n.

Eudamus aelius; Godman, 1907.

Cephise auginulus; Burns, 1996.

Cephise callicina; Burns, 1996.

GODMAN \& SALVIN (1893) thought that Eudamus auginulus was different from both C. procerus and C. aelius, but neither of the latter were in the Godman and Salvin collection (Godman 1907). Evans (1952) considered G. aelius as a synonym of Polythrix procerus. FreEMAN (1979) synonymized G. aelius and E. auginulus with $P$. procerus. BURNS (1996) agreed with GODMAN \& SALVIN (1893), correctly synonymized $E$. callicina with $C$. auginulus, but did not deal specifically with $G$. aelius. Examination of the types indicated that both $C$. anginulus and $E$. callicina are synonymous with $C$. aelius and that they are different from C. procerus. The wings and genitalia of $C$. aelius were illustrated by BuRns (1996) as $C$. anginulus including the holotype of $E$. callicina. The female type of Goniurus aelius Plötz, 1880, at ZMHB, is here designated its LECTOTYPE and has the following labels: /Jalappa Depp [?]/ 5083/ Typus/ Gen. prep. Mielke 1996/.

Distribution and phenology. The species has been recorded from Mexico (Quintana Roo), Guatemala, Honduras, Costa Rica (Guanacaste), Venezuela and Colombia (PLÖTZ 1880; GodMAN \& SALVIN 1879-1901; SCHAUS 1902; BuRNS 1996; this study). The type locality, listed as Pará [Brazil], is obviously a mistake based on the data associated with the lectotype. The records of $C$. procerus for Mexico and northern Central America (Evans 1952; FrEEMAN 1979; DE LA MAZA et al. 1991) refer, at least in part, to C. aelius (e.g., WARREN 1999); the genitalia illustrated by GODMAN \& SALVIN (1893) and FREEMAN (1979) appear to be of C. aelius and not of C. procerus. Specimens examined: Colombia: Anguani, Sierra Nevada de Santa Marta, 27 Apr. 1938 (1 female, not dissected); MeXICo: Quintana Roo; Nuevo X-Can, 30 July 1977 (1 male, not dissected); VenezUELA: Distrito Federal; Caracas, 31 Jan. 1936 (1 female, not dissected), Guárico; Estacion Biologica de los Llanos, Calabozo, 16 Dec. 1979 (1 female, not dissected); lectotype. This species or C. procerus was incorrectly reported as occurring in the United States (FREEMAN 1945, 1967).

\section{Cephise callias (Mabille, 1888)}

Figs $16,45,52-55$

Eudamus callias Mabille, 1888 (TL: Puerto Cabello, Venezuela, female type at ZMHB herein designated as the lectotype).

Goniurus callias; Mabille \& Vuillot, 1891.

Polythrix callias; Evans, 1952.

BURNS (1996) was also not certain about the identity of Eudamus callias and considered that species identified here as $C$. procerus as $C$. near callias. Examination of the types clarified the diagnosis of these two species. The type female of Eudamus 

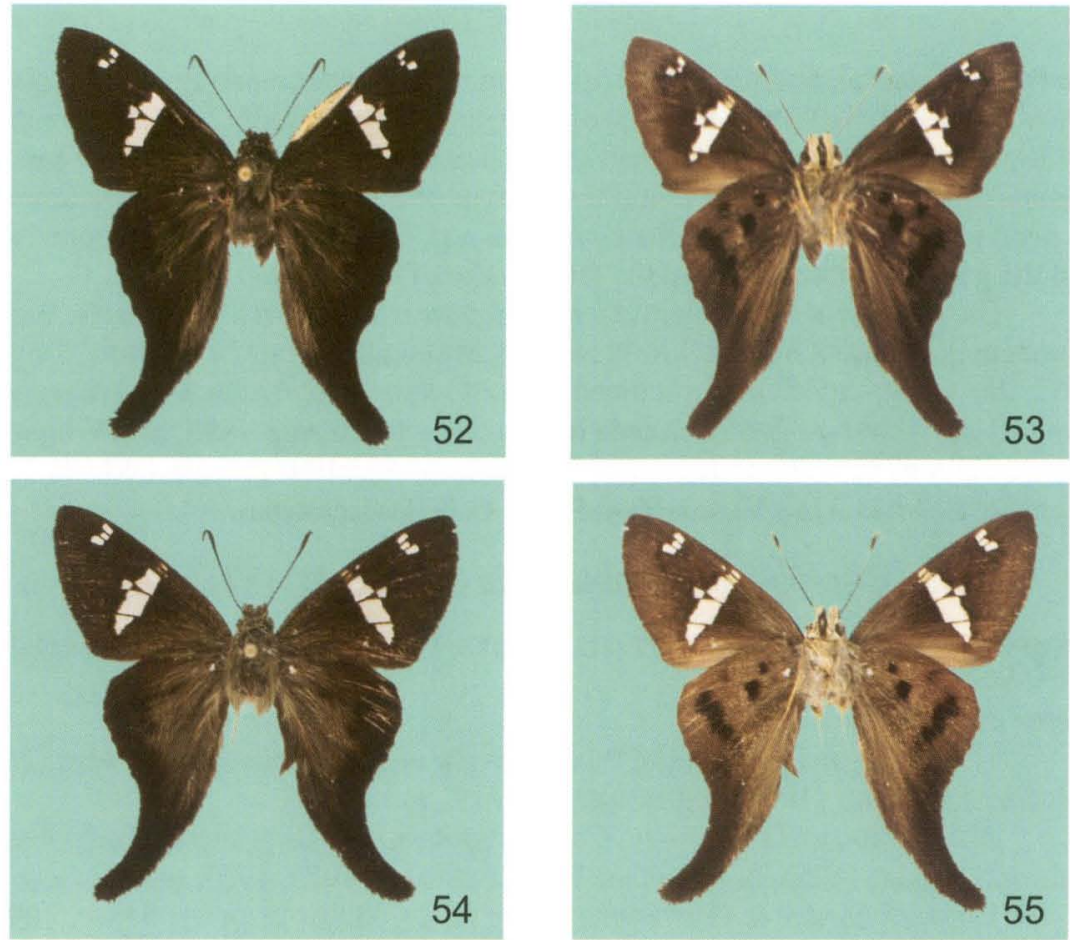

Figs 52-55. (52-53) Cephise callias male, dorsal and ventral, Peru: Huánuco, Tingo Maria, 670 m, Apr. 1997; (54-55) C. callias female, dorsal and ventral, same data as Figs 48-49.

callias at ZMHB, here designated the LECTOTYPE, has the following labels: /Origin./ Callias Mab./ G. Callias Mab./ Callias Mab./ E. Callias Mab./ Pto Cabello, Hahnel/. The species is similar to E. procerus, except the hyaline macule in forewing cell $\mathrm{M}_{3}-\mathrm{CuA}_{1}$ overlaps for half its breadth the macule in $\mathrm{CuA}_{1}-\mathrm{CuA}_{2}$ and slightly overlaps the discal cell macule (not shown well in the illustration accompanying the original description, MABILLE 1888). On the type, the dark distal macule in ventral hindwing cell $\mathrm{Sc}+\mathrm{R}_{1}-\mathrm{Rs}$ is somewhat more prominent than that on the type of $P$. procerus, about as bold as that in the base of the same cell, but this character is variable. The male genitalia of $C$. callias are very similar to those of $C$. procerus, possibly not always distinguishable. The female genitalia, however, are distinctive. These have the lamella postvaginalis shallowly U-shaped on its caudal edge. The lamella antevaginalis is well-sclerotized and broad, extends relatively further caudad, and has a V-shaped notch at its caudal edge. The sterigmal plates are relatively broad, widely spaced and not serrated and extend inward as a long and pointed projection. The ductus bursae has a sclerotized Y-shape caudad becoming membranous and bulbous cephalad where one side is partially enclosed by sclerotized plate and the corpus bursae is an oblong membranous sack.

This is the one species of tailed Cephise known from central Rondônia. The single female (the only female of Cephise seen from Rondônia), with its bold ventral hindwing markings, is similar to the female of $C$. near callias, herein considered a junior synonym of Cephise procerus (Plötz, 1880), illustrated by BuRNS (1996), 
but has a longer tail and the ventral hindwing has narrower markings and no distal macule in cell Rs-M $\mathrm{M}_{1}$. Its genitalia, however, are different from C. procerus and $C$. aelius, somewhat intermediate between those shown by BURNS (1996) for C. auginulus, herein considered a junior synonym of C. aelius (Plotz, 1880), and for C. procerus. The wings and female genitalia are like those of a female from Peru and the genitalia match those of the female type of C. callias.

Distribution and phenology. Cephise callias is known from Venezuela, Brazil (Rondônia), Peru, and Bolivia (MABILLE 1888, MABILLE \& Vuillot 1890-91, Evans 1952, this study). Specimens examined: BRAZIL: Rondônia; $62 \mathrm{~km} \mathrm{~S}$ of Ariquemes, Linha C-20, 7 km E of B-65, Fazenda Rancho Grande, 20 Aug. 1993, at MV light (1 female, GTA \#7529); PERU: Huánuco; Tingo Maria, Apr. 1997 (1 male, OM\#45.367; 1 female, OM \#45.375); Venezuela: Puerto Cabello (lectotype).

\section{Cephise guatemalaensis (Freeman, 1977)}

Polythrix guatemalaensis Freeman, 1977 (TL: GUATEMALA: Petén; Sayaxché, male holotype at AMNH).

Cephise guatemalaensis; Burns, 1996.

The wings and genitalia of this relatively unambiguous species were illustrated by FrEEMAN (1977) and BURNS (1996).

Distribution and phenology. Cephise guatemalaensis is known from Guatemala and Mexico (Chiapas, Quintana Roo) (FREEMAN 1977, 1979; DE LA MAZA et al. 1991; DE LA MAZA \& GUTIÉRREZ 1992; DE LA MAZA \& DE LA MAZA 1993; BURNS 1996).

\section{DISCUSSION}

The data herein presented include a second recent perspective on Cephise. BURNS' (1996) understanding of the genus was based on long series of reared specimens of two species from Costa Rica, the examination of types at the USNM, and a smattering of other material. This study was based upon a single diverse community with six sympatric species, a similar smattering of other specimens, and the examination of the types of several additional names associated with the genus. A combination of these two studies provides a review of nearly all that is known of the genus. Included are illustrations of the wings and genitalia of both sexes of all species except for the females of $C$. glarus and $C$. maculatus which remain unknown. Both investigations indicated a much greater species richness in the genus than imagined just a few years ago and future expansion is possible as these very rarely observed species become better known. Their study may be facilitated by rearing series (BURNS 1996), with the use of paper lures (AUSTIN et al. 1993), and the realization that their flight period is in the late afternoon and evening. Fourteen of 20 records of the genus for Rondônia were at paper lures or in association with army ants and, of the 16 timed records, all were after 1430 hrs and 12 of these were after 1630 hrs. Mielke has also seen Cephise, and other "night" skippers (AUsTIN 2000), at unidentified flowers (perhaps Inga sp.) in the late afternoon and evening. Too few records of Cephise exist anywhere to detect seasonal patterns with confidence. In Rondônia, they have been recorded from June to August (late dry season) and October to December (early wet season) with $1 / 2$ of the records in November. 
Further south in Brazil, they have been recorded in all months except October with most in May (especially Santa Catarina), August (Rio de Janeiro) and September (Espírito Santo and Rio de Janeiro).

BURNS' (1996) study indicated that Cephise included at least four untailed taxa and three taxa with long hindwing tails. This study has shown a general misapplication of names; examination of types of Eudamus cephise, Thymele hydarnes, and Telegonus glarus has allowed proper association of names and phenotypes and an assessment of synonymies, these being quite different from those in common usage. BURNS (1996) also discussed two additional tailed taxa Goniurus procerus Plötz, 1880, and Goniurus aelius Plötz, 1880 (both included in Polythrix Watson, 1893) that potentially were Cephise. These were reexamined, found to be Cephise, and a synonymy was proposed. To these, five tailless species have been added ( 1 from Mexico, 3 among material from Rondônia, Brazil, and 1 from southeastern Brazil), one described tailless taxon has been sunk into synonymy, and four tailed species have been identified. This brings the unquestioned species total of Cephise to eight untailed species and four tailed species, a vastly different picture of a genus considered to be monotypic until very recently.

ACKNOWLEDGEMENTS. We thank S. R. Steinhauser (SRS) for sharing his extensive knowledge of Neotropical Hesperiidae and Wolfram Mey (ZMHB) for permitting the study of the types. Loans of specimens were facilitated by J.E. Rawlins (CM), F. H. Rindge (AMNH) and S. R. Steinhauser (AME). P.J. DeVries is thanked for the loan of a C. nuspesez from Costa Rica. T.C. Emmel and the Harald Schmitz family provided assistance and encouragement. G. Bongiolo, J.P. Brock, O. Gomes, D. and J. Lindsley, J.D. Turner, A.D. Warren, and F. and A. West assisted in the field. The Conselho Nacional de Desenvolvimento Cientifico e Tecnológico kindly issued the authorization permits from the Ministério da Ciência e Tecnologia for our studies in Rondônia in collaboration with EMBRAPA/CPAC and the Universidade Federal do Paraná.

\section{REFERENCES}

Austin, G.T. 2000. Hesperiidae of Rondônia, Brazil: taxonomic comments on "night" skippers, with descriptions of new genera and species (Lepidoptera: Hesperiidae: Pyrginae). Trop. Lepid., in press.

Austin, G.T., J.P. Brock \& O.H.H. Mift.KF. 1993. Ants, birds, and skippers. Trop. Lepid. 4 (Suppl. 2): $1-11$.

Austin, G.T. \& O.H.H. MiELKE. 1997. Hesperiidae of Rondônia, Brazil: Aguna (Pyrginae), with a partial revision and descriptions of new taxa from Mexico, Panama, and Brazil. Revta bras. Zool. 14: 889-965.

Brown JR., K.S. \& O.H.H. MieLkE. 1967. Lepidoptera of the Central Brazil Plateau. I. Preliminary list of Rhopalocera (continued): Lycaenidae, Pieridae, Papilionidae, Hesperiidae. Jour. Lepid. Soc. 21 : 145-168.

BurNs, J.M. 1996. Genitalia and the proper genus: Codatractus gets mysie and uvydixa - in a compact cyda group - as well as a hysterectomy, while cephise gets part of Polythrix (Hesperiidae: Pyrginae). Jour. Lepid. Soc. 50: 173-216.

DE la Maza E., J.; A. Winte L. \& R. DE La Maza E. 1991. La fauna de mariposas de México. Parte II. Hesperioidea (Lepidoptera: Rhopalocera). Revta Soc. mex. Lepid. 14: 3-44.

DE LA MAZA, J. \& R.G. DE LA MAZA. 1985. La fauna de mariposas de Boca del Chajul, Chiapas, Mexico (Rhopalocera). Parte I. Revta Soc. mex. Lepid. 9: 23-44.

DE la MAZA, R.G. \& J. DE la MAZA. 1993. Mariposas de Chiapas. México, Gobierno del Estado de Chiapas, 224p. 
DE l.A MazA, R.G. \& D. Gutiérrez. 1992. Rhopalóceros de Quintana Roo, su distribución, origen y evolución. Revta Soc. mex. Lepid. 15: 1-44.

DE LA MAza E., R.G. \& A. White L. 1990. Rhopalocera de la Huasteca Potosina, su distribución, composición, origen y evolución. Revta Soc. mex. Lepid. 13: 29-87.

Draudt, M.W.K. 1921-1924. Grypocera, breitköpfige Tagfalter, p. 833-1011. In: A. SeItz (Ed.). Die Gross-Schmetterlinge der Erde, vol. 5. Die amerikanischen Tagfalter. Stuttgart: A. Kernen.

Evans, W.H. 1952. A catalogue of the American Hesperiidae in the British Museum (Natural History). Part II: Pyrginae - section 1. London, British Museum (Natural History), 246p.

FreEmAN, H.A. 1945. Notes on some skippers, with new records for the United States. Canad. Ent. 77: 201-203. 228.

. 1970. Notes on the genus Cephise Evans, with a new record for Mexico (Hesperiidae). Jour. Lepid. Soc. 24: 68-69.

- 1977. Six new species of Hesperiidae from Mexico. Jour. Lepid. Soc. 31: 89-99.

1979. Review of the Mexican Polythrix Watson 1893 (Hesperiidae). Jour. Lepid. Soc. 33: 124-128.

Godman, F.D. 1907. Notes on the American species of Hesperiidae described by Plötz. Ann. \& Mag. Nat. Hist. 20 (7): 132-155.

Godman, F.D. \& O. Salvin. 1879-1901. Biologia Centrali-Americana. Zoologia, Lepidoptera-Rhopalocera. London, Taylor \& Francis, 1269p.

HAYward, K.J. 1948. Insecta, Lepidoptera (Rhopalocera), familia Hesperiidarum, subfamiliae Pyrrhopyginarum et Pyrginarum. In H.R. DESCOLE (Ed.). Genera et species animalium argentinorum. Buenos Aires, Guillermo Kraft, Vol. 1, 389p.

L^MAS, G. 1994. List of butterflies from Tambopata (Explorer's Inn Reserve), p. 162-177. In: R.B. Foster; J.L. CARR \& A.B. Forsyth (Eds). The Tambopata-Candamo Reserved Zone of Southeastern Peru: A Biological Assessment. Washington, DC, Conservation International, Rapid Assessment Program, RAP Working Papers 6, 184p.

MABILLE, P. 1877. Diagnoses d'hespériens nouveaux. Bull. Soc. ent. France 6: CXCVII-CCII.

—. 1888. Diagnoses de Lépidoptères (Hespérides) nouveaux. Le Naturaliste 2: 98-99.

Mabille, P. \& P. Vuillot. 1890-1891. Novitates Lepidopterologicae. Paris, P. Vuillot, 161 p.

Mielke, O.H.H. \& M.M. CASAgRANDE. 1991. Lepidoptera: Papilionoidea e Hesperioidea coletados na Ilha de Maracá, Alto Alegre, Roraima, parte do projeto Maracá, com uma lista complementar de Hesperiidae de Roraima. Acta Amazonica 21: 175-210.

- 1998. Butterflies of the Ilha de Maracá, p. 355-359, 467-478. In: W. MILLIKEN \& J.A. RATTER (Eds). Maracá. The biodiversity and environment of na amazonian rainforest. Chichester, John Wiley \& Sons, 508p.

Ptötz, C. 1880. Die Hesperiinen-Gattung Goniurus Hüb. und ihre Arten. Bull. Soc. Imp. Nat. Moscou 55 (3): 1-22.

- 1881. Die Hesperiinen-Gattung Eudamus und ihre Arten. Stett. ent. Ztg. 42: 500-504.

. 1882. Einige Hesperiinen-Gattungen und deren Arten. Berl. ent. Ztschr. 26: 71-82, 253-266.

Robbins, R.K.; G. Lımas; O.H.H. Mielke; D.J. Harvey \& M.M. CaSagrande. 1996. Taxonomic composition and ecological structure of the species-rich butterfly community at Pakitza, Parque Nacional del Manu, Peru, p. 217-252. In: D.E. Wilson \& A. Sandoval (Eds). Manu, The Biodiversity of Southeastern Peru. Washington, DC, Smithsonian Institution.

Schnus, W. 1902. Descriptions of new American butterflies. Proc. U.S. Nat. Mus. 24: 383-460.

WARREN, A.D. 1999. Hesperioidea (Lepidoptera). In: J.E. Llorente BousQuETs; E. GonZÁlez SoriAno; \& N. PAPAVtro (Eds). Biodiversidad, taxonomia y Biogeografia de Artrópodos de México: Hacia una Sintesis de su Conocimiento. Mexico City, Inst. Biologia, UNAM \& CONABIO, Vol. II, in press.

Recebido em 05.IV.1999; aceito em 25.VIII. 2000 